\title{
PENGARUH ATTACHMENT BASED FAMIY THERAPY (ABFT) TERHADAP PEMENUHAN KEBUTUHAN PSIKOLOGIS ANAK YANG MENGALAMI KETERLANTARAN DI DESA CIKOLE KECAMATAN LEMBANG KABUPATEN BANDUNG BARAT
}

\author{
Mahatir Muhammad ${ }^{1}$, Susilawati $^{2}$, Tuti Kartika ${ }^{3}$ \\ ${ }^{1}$ Universitas Binawan \\ ${ }^{2,3}$ Politeknik Kesejahteraan Sosial Bandung \\ Email: athi69_@yahoo.com
}

\begin{abstract}
Abstrak
Penelitian ini bertujuan untuk mengkaji pengaruh terapi Attachment Based Family Therapy (ABFT) yang berpengaruh pemenuhan kebetuhan psikologis anak yang mengalami keterlantaran. Aktivitas orang tua dalam membangun attachment dengan memuji, mendampingi, dan membelai menjadi fokus intervensi dalam penelitian ini. Pendekatan penelitian yang digunakan yaitu penelitian kuantitatif dengan menggunakan Single Subjeck Desain (SSD). Model penelitian yang digunakan yaitu A-B-A yang terjadi dari tiga fase anatara lain. Fase A1 (baseline), Fase b (Intervensi), dan fase A2 (hasil) dengan menggunaka dua subyek yaitu AC dan HN. Instrumen yang digunakan adalah lembaran pencatatan observasi prilaku. Teknik pengumpulan data yang digunakan antara lain observasi, wawancara, angket, studi dokumentasi dan pencatatan produk permanen. Data yang di peroleh dianalisis dengan cara pembuatan grafik, pembuatan statistik deskriptif, dan analisis inpeksi visual. Analisis inspeksi visual terdiri dari analisis dalam kondisi dan antar kondisi. Hasil penelitian menunjukkan penerapan Attachment Based Family Theapy (ABFT) efektif untuk meningkatkan attachment kepada orang tua ke anak sehinga efektif dalam meningkatkan pengaruh dalam pemenuhan kebutuhan psikologis anak merasa mendapatkan kasi sayang, merasa dilindungi dan merasa didampingi. Rekomendasi penilitan ini di tujukan kepada pekerjaan sosial untuk menangani permasalahan anak kurang mendapatkan Atttacment dari orang tuanya. Bagi penelitian lanjutan disarankan menggambangkan terapy attachment yang lebih pesifik dan fleksibel dalam meningkatkan kebutuhan-kebutuhan anak.
\end{abstract}

Kata Kunci: Attachment Based Famiy Therapy (ABFT), Kebutuhan Psikologis, Anak Terlantar.

\section{Abstract}

This study aims to examine the influence of Attachment Based FamilyTherapy (ABFT) therapy toward the Efforts to Increasing Fulfillment of children Psychological Needs Who unattended.Parent's activities to build attachments by praising, accompanying, and caressing are focus of intervention in this research. The research approach is quantitative research using Single Subjeck Design (SSD). The research model used is A-B-A which occurs from three phases of the other. Phase A1 (baseline), Phase $b$ (Intervention), and phase A2 (result). The instrument used is the behavior observation quotation sheet. Data collection techniques such as observations, interviews, questionnaires, documentation studies and recording of permanent products. The data obtained were analyzed by way of graph making, descriptive statistics, and visual inpection analysis. Visual inspection analysis consists of analysis under conditions and inter conditions. The result of the research shows that Attachment Based Family Theapy (ABFT) application is effective to improve the attachment to the parents so that it is effective in improving fulfilling the psychological needs of the 
children feel they are getting the counseling, feel protected and feel accompanied. Keywords: Attachment Based Family Therapy (ABFT), praise, accompany the children. The recommendation of this research is directed to social work to deal with the problem of children less getting Atttacment from their parents. For advanced research, it is suggested to symbolize the more flexible and flexible attachment in increasing the needs of the children.

Keywords: Attachment Based Family Therapy (ABFT), Psychological Needs, Neglected Children.

\section{A. PENDAHULUAN}

Jumlah anak terlantar setiap tahunya mengalami peningkatan baik itu di tingkat provinsi maupun kota. Data rekapitulasi anak terlantar tahun 2011 di jawa barat 126.243 jiwa sedangkan pada tahun 2012 menunjukkan angka 128.045 jiwa yang tersebar di 17 kabupatan 9 kota diakses dari www.perwakilan.jabarprov.go.id dan www.dinsos.jabarprov.go.id Salah satunya kabupaten bandung barat jumlah anak yang mengalami keterlantaran berdasarkan data Badan Pusat Statistik tahun 2017 berjumlah 1345 jiwa yang perlu mendapatkan perlindungan.

Anak terlantar mengalami permasalahan tidak memiliki identitas (surat kenal lahir, akte kelahiran) menyebabkan anak rawan terhadap diskriminasi dan eksploitasi, rawan terhadap perlakuan salah (child abuse) dan berkonflik dengan hukum, dan dalam kebutuhan psikologis yang tidak terpenuhi seperti kebutuhan rasa aman, rasa cinta dan aktualisasi diri. Selanjutnya bila dilihat dari partisipasinya, maka permasalahan yang dialami anak terlantar antara lain kurangnya penghargaan terhadap pendapat anak, rendahnya kesempatan untuk menyalurkan aspirasi baik di lingkungan keluarga maupun masyarakat, belum memadainya wadah untuk berpartisipasi dan permasalahan anak terlantar jika diabaikan akan menimbulkan dampak negatif pada tumbuh kembang anak.

Salah satu dampak dari yang dialami anak terlantar adalah tidak terpenuhinya kebutuhan psikologisnya, sehingga menimbulkan suatu kecenderungan untuk melakukan halhal yang sebenarnya tidak wajar. Misalnya sebagai anak jalanan, pengamen, dan bahkan bisa melakukan disorganisi sosial seperti melacurkan diri, mencuri, dan terjerumus untuk menggunakan narkotika dan obat terlarang. Kondisi demikian dapat terjadi bila anak yang diterlantarkan oleh orang tuanya tidak mendapat perhatian dan kontrol sosial dari lingkungannya. Mereka diterlantarkan oleh orang tua dan diterlantarkan oleh lingkungannya sendiri atau diabaikan oleh masyarakat di sekitarnya sehingga hal ini perlu mendapat perhatian dari pemerintah.

Penanggulangan anak terlantar ini memerlukan adannya keterlibatan langsung profesi pekerja sosial anak sebagai orang yang terlatih dan terdidik secara profesional. Pelayanan yang diberikan oleh pekerjaan sosial anak bagi anak-anak yang mengalami keterlantaran menjadi hal yang primer, tujuannya agar anak dapat berfungsi secara psikis, sosial, dan fisiknya. Profesi pekerjaan sosial anak harus dibekali kemampuan dan kopetensi dalam bidang penanganan masalah anak yang diperoleh melalui pelatihan atau pendidikan formal di perguruan tinggi. Keterlibatan dan kerja sama aktif dari berbagai multidisipliner dan instansi yang terkait mempermuda pekerja sosial untuk memperoleh akses layanan yang diperlakukan anak dan keluarga secara tepat, berkelanjutan maka disiplin ilmu memerlukan wadah dalam melakukan praktek sebagai laboratirum pekerja sosial.

Dampak dari keterlantaran pada anak di Desa Cikole anak menggalami gangguan dalam pendidikan akibat orang tua kurang mengerti tentang hak dan kebutuhan anak, selain itu anak yang dilantarkan yang jauh dari kasi sayang berpengaruh pada relasi dalam keluarga yang kurang kelekatan dari orang tua sehingga tidak mendapatkan perlindungan dan pengawasan dari keluarga yang tidak menutup kemungkinan akan terjerumus dalam lingkungan yang salah. Pengaruh penyebab terjadinya keterlantaran di Desa Cikole karena orang tua masi minim pemahaman dalam melakukan pengasuhan dan terdapat anngapan 
dengan marahi anak membuat akan membuat anak menjadi patuh, namun sebaliknya akan mengurangi kelekatan antara oang tua dan anak.

Kelekatan dari orang tua untuk anak berpengaruh pada pemenuhan kebutuhan psikologis, dampak positif dalam kelekatan membuat anak merasa di perhatikan dan akan menumbuhkan rasa aman sehingga menumbuhkan kepercayaan. Namun yang terjadi antara orang tua dan anak kurang melakukan relasi sehingga sulit membangun kelekatan secara emosional, situasi seperti ini berdampak pada kemampuan anak dalam menyesuaikan diri kerena anak cenderung mudah cemas dan kurang percaya diri. Orang tua yang tidak melakukan kelekatan pada anak membuat anak tidak merasa percaya diri jika berada di lingkungan sosialnya, kebutuhan rasa aman yaitu kebutuhan anak dalam lingkungnnya tidak stabil dan aman. Kebutuhan ini penting bagi pembentukan karakter anak karena lingkungan yang berubah-ubah akan membahayakan perkembangan emosional anak.

Berdasarkan permasalahan diatas hasil dari kegiatan praktikan SP-1 STKS Bandung dalam kajian anak dan keluarga yang akan dilajutkan sebagai penelitian tindakan lanjutan, gambaran permasalahan didapatkan dari klien yang akan dijadikan subyek sebagai anak yang mengalami permasalasalahan keterlantaran. Peramasalan yang dialami klien HN,dan AC kurang mendapatkan pemenuhan kebutuhan psikologis yang dilakukan dari orang tua. Klien HN sering mendapatkan perlakuan kasar dari orang tuanya ( sering dimarahi) jika HN melakukan kesalahan dan tidak mendengarkan arahan dari orang tua. Perlakuan yang dialami $\mathrm{HN}$ berpengaruh pada hubungan orang tua dan $\mathrm{HN}$, sehingga $\mathrm{HN}$ terkadang malas berada di rumah. selian itu hubungan komunikasi dengan orang tua jarang dilakukan oleh HN karena takut mengungkapkan pernyataan dan perasaan jika ingin menyampaikan sesuatu. Kesibukan orang tua yang berdagang membuat kebutuhan $\mathrm{HN}$ tidak dapat terpenuhi.

Permasalahan yang dialami klien HN dapat disimpulkan kebutuhan psikologis anak yang tidak terpenuh, Klien AC juga terkadang orang tua mengabaikan tindakan yang dilakukan AC tampa melihat resiko yang terjadi pada AC dan menunjukkan ketidak aman di lingkungannya. Selain itu orang tua membebaskan kepada $\mathrm{AC}$ hal yang ingin dilakukan yang berdampak pada pergaualan bebas AC mengkonsumsi minuman keras bersama dengan temannya. Cara orang tua memberikan teguran kepada AC dengan memberikan kekerasan secara emosional, terkadang orang tua memarahi AC dan mengeluarkan kata-kata yang negatif kepada klien AC namun AC yang melakukan perlawanan sehingga terjadi konflik di dalam keluarga sehingga orang tua tidak ingin lagi menegur dan menyapa AC karena tingka lakuhnya.

Dampak klien AC mendapatkan tindakan pengabaian kurang mendapatkan kasi sayang dari orang orang tua, konflik yang terjadi pada klien AC berpengaruh pada pemenuhan kebutuhan AC. AC mengalami hubungan relasi dengan orang tuanya, terkadang orang tua memarahi AC ketika AC hanya berdiam diri dan bermalas-malasan di rumah. Tindakan yang dilakukan oleh orang tua terkadang mengabaikan AC bahkan hak dan kebutuhan AC tidak terpenuhi, perlaukan orang tua kepada AC berpengaruh pada hubungannya karena orang tua membiarkan hal yang dilakukan AC secara bebas bahkan hubungan orang tua dengan AC jarang melakukan interaksi kepada anak-anaknya. sehingga gambaran permasalahan $\mathrm{HN}$ dan $\mathrm{AC}$ perlu penganan intervensi dengan Atttachment Based Family Therapy (ABFT).

Gambaran permasalahan ketiga klien $\mathrm{HN}$, dan AC mengalami masalah dalam hubungan yang diakibatkan tindakan keterlantaran yang dilakukan orang tua berpengaruh pada kebutuhan psikologis pada anak, karena orang tua kurang mahami pola pengasuhan dalam meningkatkan kelekatan kepada anak dan pengaruh dari pemahaman orang tua dalam melakukan pengasuhan kepada anak, selain itu hubungan orang tua dan anak cenderung mengabaikan anak dan memerikan perlakuan kasarar secara verbal menjadi masalahan konflik dalam hubungan antara orang tua dan anak. ABFT terapi ini sangat penting karena 
diperuntukkan bagi keluarga yang mengalami masalah kerenggan hunbungan antara anggota keluarganya.

Membangun keluarga sebagai kekuatan dalam pemecahan masalah di antara anggota keluarga. fokus dalam penerapan terapi ini di tujukan kepada orang tua klien HN dan AC. Fokus utama dalam ABFT untuk membantu keluarga dengan mengidentifikasikan dan mendiskusiakn serta konflik yang menggangu kedekatan antara anak dan orang tua, seperti yang disebabkan oleh pengabaian, kelainan, dan penyalagunaan lingkungan pengasuhan yang keras sehingga mempengaruhi dalam perkembangan anak sehingga penerapan ABFT memiliki tujuan dalam meningkatkan relasi antara anak dan orang tua.

Intervensi Atttachment Based Family Therapy bertujuan memberikan bantuan dalam mengidentifikasikan permasalahan konflik yang terjadi pada keluarga dan Keluarga yang berfungsi sebagai sumber yang potensial dalam meningkatkan tugas perkembangan dan kebutuhan anak Proses pelaksanaan intervensi. proses ABFT yang dilakukan pada kedua klien $\mathrm{AC}$ dan $\mathrm{HN}$ untuk mencapai tujuan dikembangkan melalui lima tahap yaitu tugas pembentukan kembali (the reframing realtionship), tugas membangun kerja sama ( the Adolescent Alliiance building task), tugas kelekatan (the attacment task) dan tugas menigkatkan kompetensi (The Competency Promoting Task).

Tugas membangun kerja sama dengan orang tua (the parent alliance) building task) hal pertama yang dilakukan tugas membangun kembali hubungan, dalam kegitan ini meningkatkan kesadaran pada anggota keluarga akan pentingnya dalam megatasi permasalahan yang dialami klien HN dan AC. Keluarga akan sepakat untuk merubah fokus keluarga yang selalu menggap bahwa anak sulit diatur, pembantah dan tidak mendengarkan nasehat orang tua, namun kelemahan dalam proses intervensi yang dilakukan pada kedua klien orang tua sulit komitmen untuk dan konsisten pada fokus kegiatan yang telah di sepakati.

Tahap selanjutnya tugas membangun kerja sama dengan anak ( the Adolescent Alliiance building task). Proses kegiatan yang dilakukan praktikan bersama dengan orang tua mengajak untuk bersedia menjelaskan permasalahan yang dialami selama hal yang menggau dalam proses pengasuhan yang didapatkan oleh anak. namun dalam tahap ini kedua klien AC dan HN terlihat sepenuhnya belum menyakini yang dirasakan dan diiginkan, kedua klien terkadang menujukkan sikap tidak terbuka dan ragu untuk menyampaikan keluahan dan harapan untuk ke orang tuanya.

Tahp selanjutnya praktikan melakukan kerja sama dengan orang tua (the parent alliance bulding task). Kegiatan ini diharapkan orang tua menyadari akan pentingnya terapi yang dilakukan memahami penyebab terjadinya permasalahan yang dialami pada klien $\mathrm{HN}$ dan AC, Tahap ini orang tua bersedia menjalankan tugas dan bersedia mendengarkan apa yang dirasakan kedua klien. Dalam tahap ini masi terlihat prilaku orang tua klien yang sering mengabaikan anak, angapan bahwa dengan memarahi anak akan meningkan kedisiplinan keapda anak dan menyalahkan anak .

Pada tahap tugas kelekatan (the attachment task) kedua pihak orang tua dan anak mulai saling memahami dan duduk membahas persoalan diantara orang tua dan anak, dimana dalam tahap ini orang tua menyadari prilaku HN dan AC yang kurang mendapatkan perhatian dari orang tua, baik dalam mengontrol, memberikan pujian, kebutuhan memberikan sentuhan kepada anak. namun kendala yang terjadi orang tua kurang percaya diri memberikan perlakuan sehingga muncul ketidak kosistenan orang tua yang kurang memberikan attachment kepada anak. dan tahap terakhir tugas meningkatkan kompetensi ( the competency promoting task), hasil ini klien AC dan $\mathrm{HN}$ menunjukkan prilaku yang baik dan orang tua mampu melakukan attacment kepada anak.

Hasil kegiatan Intervensi yang telah dilakukan dalam terapi ABFT untuk memperkuat atau memperbaiki ikatan kelekatan antara orang tua dan anak sehingga akan meningkatkan 
komunikasi anatara anggota keluarga. Komunikasi interpersonal yang tidak efektif dalam keluarga mengakibatkan konfik dalam keluarga sehingga berpengaruh pada pemenuhan kebutuhan psikologis pada anak. Hal ini dikarenakan adanya presepsi yang berbeda pada saat melakukan interaksi. Orang tua perlu menyadari bahwa mereka berperan pembentukan konsep diri anak yang akan beranjak pada usia anak karna prilaku yang dimunculkan kepada anak yang kurang mendapatkan attachment berdampak negatif pada anak dan mencarai kenyaman di lingkungan lain tampah orang tua memperhatikan resiko yang akan terjadi pada anak.

Gambaran permasalahan intervensi yang dilakukan dalam penelitian yaitu dengan meningkatkan hubungan orang tua dan anak hubungan anak dengan orang tua yaitu melalui penerapan terapi ABFT dan memilih subjek orang tua klien $\mathrm{HN}$ dan AR . Intervensi yang perna dilakukan selama masa praktikum SP-1 STKS Bandung dalam kajian pelayanan anak dan keluarga mengimplementasikan terapi ABFT yang mengasilkan perubahan. Terlihat pada hubungan klien dengan orang tua mampu meningkatkan relasi kepada anak dan keluarga yang terjalin dengan baik, keluarga mampu memberikan perhatian dan kebutuhan anak selama masa pemberian intervensi yang dilakukan, namun hasil refelksi yang perlu ada peningkatan dalam tahap intervensi pada ketiga klien. Namun kendala yang didapatkan dalam proses intervensi yang dilakukan kedua klien orang tua kurang percaya diri dan masi tidak konsisten dalam prilaku kelekatan kepada anak.

Penjelasan dalam terrapi ABFT menjadi salah satu alasan peneliti dalam melanjutkan intervensi mikro dalam kegiatan penelitan. Kondisi akhir ke tiga klien dijadikan baseline, dalam kegiatan penelitian melakukan reasesmen untuk melihat kondisi klien HN dan AC . Pelaksanaan intervensi dengan menggunakan pendekatan tersebut memungkinkan timbulnya rasa bosan dari keluarga dan anak sehingga peneliti mengupayakan strategi untuk mendapatkan hasil yang maksiamal. Startegi dalam penggunaan terapi membuat hal yang menarik sesuai dengan hal yang paling disenangi oleh keluarga. Dorongan bagi peneliti untuk melanjutkan penaganan masalah subjek penelitian klien " $\mathrm{HN}$ dan AC masalah hubungan orang tua dan anak agar mendapatkan pengasuhan dengan baik dan meningkatkan hubungan relasi orang tua dengan anak dan menjadi penganan komunitas orang tua yang mengalami permasalahan yang sama.

Berdasarkan gambaran hasil praktikum peneliti tertarik untuk meneliti dan menguji penerapan Atttachment Based Family Therapy (ABFT) dalam melihat pengaruh terapi terhadap peningkatan kebutuhan psikologis anak, hasil penelitian ini diharapkan dapat dijadikan model penanganan yang dilakukan oleh pekerjaan sosial dalam mengatasi masalah anak yang kurang mendapatkan attachment dari orang tua.

\section{B. METODE PENELITIAN}

Penelitian ini menggunakan pendekatan kuantitatif dengan desain subyek tunggal/single subject design. Unit analisis dalam penelitian ini tunggal yaitu orang tua klien $\mathrm{HN}$ dan AC Penelitian dengan desain subyek tunggal merupakan salah satu metode evaluasi yang digunakan dalam praktek pekerjaan sosial untuk mengevaluasi suatu teknik atau program yang sebelumnya pernah dilakukan pada praktikum SP-1 di Desa Cikole. Evaluasi ini dilakukan langsung pada perilaku dalam waktu yang telah ditentukan setelah orang tua menerima pemahaman mengenai kebutuhan dan hak anak.

Peneliti melakukan monitoring orang tua klien HN, dan AC dan berkelanjutan selama pelaksanaan penelitian, terhadap hubungan antara orang tua dan anak. Selama melakukan monitoring peneliti melakukan pengukuran terhadap kehangatan secara berulang-ulang sebelum dan sesudah intervensi dengan periode waktu per minggu. Oleh karena itu, penelitian ini dapat melihat sejauh mana kelekatan yang di lakukan orang tua terhadap anaknya. 
Model rancangan penelitian yang digunakan yaitu model A1-B1-A2. A1 menunjukkan kondisi baseline kelekatan pada keadaan natural sebelum dilakukan intervensi. Sedangkan B menunjukkan kondisi intervensi, yaitu kondisi ketika pemahaman tentang kelekatan diberikan diberikan yang di pahami oleh orang tua . A2 adalah situasi kelekatan yang dilakukan oleh orang tua setelah melakukan intervensi dalam memberikan pemahaman tentang pengasuhan. Dalam penelitian desain subyek tunggal selalu dilakukan perbandingan dengan subyek yang sama dalam kondisi yang berbeda.

Prosedur dasar yang dilakukan pada model A1-B1-A2 dilakukan pengukuran target perilaku secara continue pada kondisi baseline (A1) dengan periode waktu tertentu, kemudian dilanjutkan dengan pengukuran pada kondisi intervensi (B1), terakhir dilakukan pengukuran baseline kembali pasca intervensi (A2). Pengukuran pada kondisi baseline 2 (A2) ini dimaksudkan sebagai kontrol untuk kondisi intervensi.

Subyek dalam penelitian ini menggunakan subyek tunggal, di mana perilaku setelah diberi perlakuan dibandingkan dengan perilaku sebelum diberi pelakuan (baseline). Subyek dalam penelitian ini adalah $\mathrm{HN}$ dan AC yang mengalami hubungan realasi antara orang tua dan anak, kemudian memberikan bantuan untuk mengidentifikasi permasalahan konflik. Tujuan dalam pererapan terapi ABFT meningkatkan hubungan kasi sayang yang orang tua ikut berpartisipasi dalam tujuan bersama.

Penelitian ini menggunakan alat ukur yang disusun sedemikian rupa oleh peneliti, yang mencakup daftar pertanyaan tentang mengenai hubungan kelekatan hubugan emosional yang dilakukan oleh orang tua dan anak.

Instrumen atau alat ukur yang digunakan dalam penelitian ini, adalah :

1. Skala hubungan emosional

hubungan emosional bertujuan untuk mengetahui kemampuan subyek dan orang tua dalam melakukan kegiatan-kegiatan yang bertujuan untuk memenuhi kebutuhan hidupnya dan menjalankan tugas untuk meningkatkan relasi, mengurangi pengabaian terhadap anak dan menigkatkan hubungan yang baik antara Subyek dan klien. Aspekaspek yang diukur antara lain : inisiasi, ekplorasi. intetifikasi, formalisasi, intetifikasi dan deteriorasi

2. Pedoman observasi

Peneliti menggunakan pedoman observasi sebagai alat ukur untuk menghitung prilaku yang di munculkan sesuai dengan perilaku target yang akan dicapai dalam periode waktu tertentu, baik dalam mengukur baseline, fase intervensi maupun fase akhir.

3. Pedoman wawancara

Peneliti menggunakan pedoman wawancara untuk mengetahui lebih dalam permasalahan dan faktor-faktor apa yang mendorong terjadinya hubungan kurang baik antara orang tua dari HN dan AC. Pedoman wawancara juga digunakan untuk menggali informasi mengenai $\mathrm{HN}, \mathrm{AC}, \mathrm{AD}$ dan orang tua, dalam hal ini berkaitan dengan hubungan yang akan diamati oleh peneliti.

Instrumen yang valid dan reliabel merupakan syarat yang mutlak untuk mendapatkan hasil penelitian yang valid dan reliabel. Sugiyono (2012:121) menyatakan bahwa instrumen yang valid berarti instrumen yang dapat digunakan untuk mengukur apa yang seharusnya diukur. Sedangkan instrumen yang reliabel merupakan instrumen yang apabila digunakan untuk mengukur obyek yang sama, akan menghasilkan data yang sama. Instrumen-instrumen dalam ilmu sosial memang sudah ada yang baku karena telah teruji validitas dan reliabilitasnya, tetapi ada juga yang belum baku bahkan tidak ada. Oleh karena itu, peneliti perlu menyusun sendiri instrumen dan menguji kembali validitas dan reliabilitas instrumen yang akan digunakan dalam penelitian. Adapun di bawah ini validitas dan reliabilitas alat ukur sebagai berikut: 
Dalam Sugiyono (2012:123) menyatakan bahwa instrumen yang valid perlu memiliki validitas internal dan validitas eksternal. Validitas internal dikembangkan berdasarkan teori yang relevan sedangkan validitas eksternal disusun berdasarkan fakta-fakta empiris yang telah ada. Validitas yang digunakan dalam penelitian ini yaitu validitas kontruksi. Penetapan validitas kontruksi ini dikarenakan instrumen penelitian yang digunakan lebih mengarah pada pengukuran sikap, pendapat, atau persepsi seseorang. Pengujian validitas konstruksi menggunakan pendapat dari ahli, dalam hal ini setelah instrumen dikontruksikan tentang aspek-aspek yang akan diukur berdasarkan teori penelitian, maka selanjutnya dikonsultasikan dengan tim peneliti yang ain melalui seminar proposal penilitian. Setelah pengujian kontruksi dari tim peneliti lain disetujui, maka diteruskan dengan uji coba instrumen.

Selanjutnya, setelah data diperoleh maka ditabulasikan dan dilakukan dengan analisis faktor yaitu dengan mengkorelasikan antar skor item instrumen dalam suatu faktor dan mengkorelasikan skor faktor dengan skor total. Uji validitas alat ukur yang digunakan adalah uji statistik dengan rumus korelasi product moment dari Pearson, yaitu:

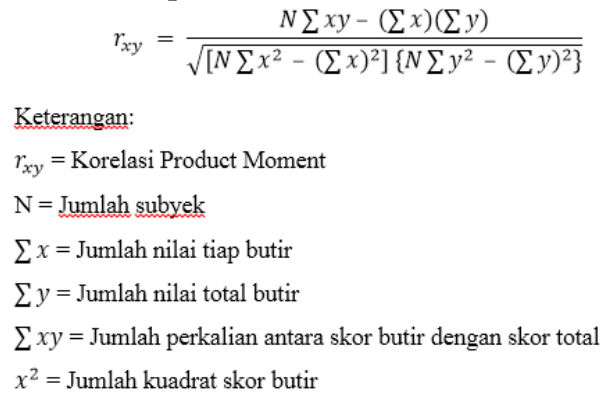

Validitas sebuah data harus didukung oleh reliabitasnya agar hasil yang diperoleh menjadi lebih akurat dan diakui kebenarannya. Reliabilitas dapat menentukan kualitas penelitian dan menunjukan sejauhmana data yang diperoleh dapat diukur secara ajeg dan tepat. Pengujian reliabilitas alat ukur dalam penelitian ini menggunakan pengujian internal consistency. Pengujian ini dilakukan dengan cara menguji coba instrumen sekali saja, kemudian data yang diperoleh dilakukan analisa dengan uji koefesien Alpha Croncabch, dengan rumus sebagai berikut:

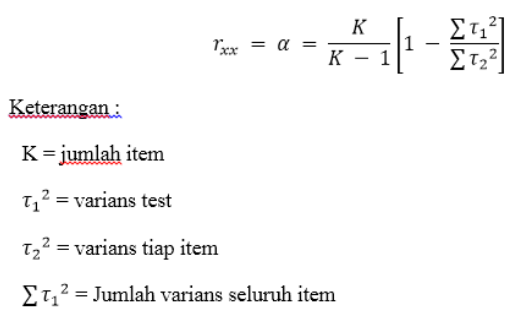$$
r_{x x}=\alpha=\frac{K}{K-1}\left[1-\frac{\sum \tau_{1}^{2}}{\sum \tau_{2}^{2}}\right]
$$

Secara empirik, bahwa tinggi rendahnya reliabitas ditunjukkan oleh suatu angka yang disebut koefisien reliabilitas, angka koefesien reliabilitas berada dalam rentang 0,0 sampai 1,0, artinya bahwa semakin koefisien mendekati angka 1,0 berarti semakin tinggi reliabilitasnya. Namun sebaliknya, jika koefisien reliabitasnya mendekati 0,0 artinya bahwa reliabilitasnya semakin rendah. Pengujian reliabilitas alat ukur ini menggunakan program komputer SPSS versi 22.0.

Teknik pengumpulan data yang digunakan dalam penelitian ini adalah angket dan observasi. Teknik analisis data yang digunakan dalam penelitian desain subyek tunggal yaitu analisis visual dengan menggunakan statistik deskriptif yang sederhana. Tujuan utama analisis data dalam bidang modifikasi perilaku yaitu untuk mengetahui efek atau pengaruh intervensi terhadap perilaku sasaran yang ingin diubah (Sunanto, 2006:65). Adapun komponen analisis data dalam penelitian ini antara lain:

1. Analisis dalam kondisi 
Pada tahap ini, peneliti melakukan analisis terhadap perubahan data yang terjadi pada suatu kondisi yaitu kondisi baseline atau kondisi intervensi. Komponen yang dianalisis dalam kondisi ini meliputi panjang kondisi, kecenderungan arah, tingkat stabilitas, tingkat perubahan, jejak data, dan rentang.

2. Analisis Antar Kondisi

Peneliti melakukan analisis perbandingan antara kondisi baseline dengan kondisi intervensi. Kegiatan analisis ini dapat dilakukan apabila kondisi sudah dapat dikatakan stabil dan tidak terjadi overlap. Komponen utama yang perlu dianalisis meliputi jumlah variabel yang diubah, perubahan kecenderungan dan efeknya, perubahan stabilitas, perubahan level, dan data tumpang tindih (overlap). Perlu diingat bahwa dalam melakukan analisis antar kondisi ini, kondisi baseline dan kondisi intervensi perlu memiliki tingkat stabilitas yang konstan.

\section{HASIL DAN PEMBAHASAN Kondisi Keluarga HN}

Penelitian ini menggunakan dua subjek antaralain HN dan AC. Klien HN merupakan anak pertama dari dari pasangan ibu EU dan bapak AS, ibu EU telah melakukan pernikahan 4 kali dan bapak AS adalah suami 4, dalam proses ini praktikan hanya memasukkan pasangan dari suami ke 4 ibu UE. Pendidikan terakhir ibu UE adalah SD (sekolah dasar) dan pekerjaan ibu menjual pakaian namun barang yang didagankan bukan miliknya namun ibu UE hanya jasa menjual barang. Penagsilan ibu UE tidak menentu sehingga sulit untuk memenuhi kebutuhan anak. Ibu UE meuali berdagang pagi sampai malam sehingga anak berada di rumah sendirian. Ibu EU telah melakukan pernikahan sebanyak empat kali dan melakukan perceraian selama empat kali

Permasalahan klien HN rentan mengalami putus sekolah melanjukan sekolah karana kondisi ekonomi keluarga, aktivitas yang dilakukan HN selama sekolah menjaga adikadiknya ketika ibu UE bekerja. Berdasarkan hasil wawancara ayah HN tidak diketahui keberadaannya dan tidak perna memberikan kabar kepada ibu HN. HN yang mengalami permasalahan dalam pendidikan membuat ibu UE berharap kepada $\mathrm{HN}$ walaupun tidak sekolah $\mathrm{HN}$ akan sukses dan pasrah dengan kondisi klien.

Klien HN pernah mengalami hal yang mengecewakan, klien perna di marahi oleh ayahnya ketika ingin melakukan sesuatu dan hal ini membuat klien kecewa karena orang tua melakukan tindakan kekerasan kepada anak. Hal yang membuat bahagia klien ketika mendapatkan hadia dari pertandingan HUT RI. Selian itu pengalaman yang menyedikan yang di dapatkan oleh klien HN pada waktu masi sekolah klien HN mendapatkan prilaku Bullying dari temanya sehingga klien malas untuk menlanjutkan sekolah. Salain itu pengalaman klien dengan ibunya juga perna memarahi klien HN dan terkadang klien $\mathrm{HN}$ tidak mendapatkan perhatian karena ibu yang sedang sibuk berjualan

Klien tinggal di desa Cikole dari lahir sampai sekarang masih tinggal di Desa Cikole, klien tidak pernah menagalami perpidahan. Orang tua klien bekerja menjual baju namun baju yang dijual adalah barang milik orang, pengasilan ibu klien tidak menentu ibu klien mendapat upah jika baju yang dijual laku dan pemilik baju membayar ke ibu klien satu baju yang laku Rp.5000. keuarga klien mendapatkan sebagian bantuan dari prgram pemerintah, namun kedala untuk mengurus prosedur sebagai penerima manfaat klien sulit karena kelengkapan adrimistrasi klien yang belum lengkap. Ibu klien yang sebagai tulang punggu keluarga untuk memenuhi kebutuhan anak-anaknya, ibu klien yang di tinggal cerai oleh suami dan ibu klien tidak mengetahui keberadaan ayah HN. Dalam kondisi ini ibu sangat berperan dalam mpengasuhan anak. Berdasarkan hasil wawancara yang dilakukan praktikan bersama dengan klien $\mathrm{HN}$ ibu jarang di rumah dan ketika HN menyampaikan sesuatu klien HN terkadang di marahi. 


\section{Kondisi Keluarga AC}

AC merupakan anak pertama dari 2 bersodara adik klien adalah laki, berdasrkan hasil wawancara yang dilakukan praktikan dengan ibu klien adalah anak rajin ketika mendapatkan amanah dari orang tua, pendidikan terakhir ayah klien adalah SMP dan ibu juga pernah mengalami putus sekolah, kondis ekonomi keluarga klien termasuk dalam kategori menengah kebawah, orang tuanya masih dapat memenuhi kedua anaknya dengan baik walaupun segala sesuatunya masih berkecukupan tetapi orang tua klien masih mampu memenuhi kebutuhan klien.walaupun penghasian sehari-hari klien hanya bergantung pada ibu klien karena ayah klien walaupun kerja tetapi penghasilannya tidak menentu tetapi hal tersebut bukan menjadi masalah besar untuk ibunya asalkan ketiga anak nya dapat terpenuhi kebutuhan sehari-harinya walaupun hanya pas-pasan sehingga salah satu masalah keluarga Klien AC yang mengalami putus sekolah karena kodisi ekonomi keluarga.

Keberfungsian sosial klien dapat terlihat dari kemampuan klien berinteraksi dengan lingkungan sosialnya dalam memenuhi kebutuhannya, memecahkan masalahnya, dan menjalankan peranannya sesuia status sosialnya. Klien AC cukup menutup diri dilingkungan rumahnya karena SO merasa minder dengan teman-teman seusianya yang berada di lingkungan rumahnya walaupun sebelumnya klien AC. Berdasarkan hasil wawancara dan observasi bersama keluarga, AC lebih banyak beraktifitas di rumah dan di kamar dan terkadang orang tua hanya membiarkan klien berakatifitas dengan yang lain.

Klien AC lebih senang beraktifitas didalam rumahnya akibat minder dengan temantemannya, alasan klien AC minder karena teman yang lain bersekolah sedang AC hanya berdiam diri dirumah. Sehingga Orang tua AC membabaskan AC dalam melakukan aktifitasnya dan terkadang orang tua tidak meberikan perhatian ke AC karena AC tidak mendengarkan perkataan orang tua dan memunculkan perasaan malas untuk melakukan interaksi dengan klien AC. Selain itu menggunakan ecomap untuk mengetahui hubungan sosial yang menggarkan kondisi hubungan sosial subyek $\mathrm{AC}$ baik dalam lingkungan keluarga, teman dan temapat tinggalnya dimana dalam penggunaan tools asesmen ini akan mendapatkan hubungan-hubungan subyek $\mathrm{HN}$ baik dapat dimanfaatkan sebagai proses sumber dalam penelitian

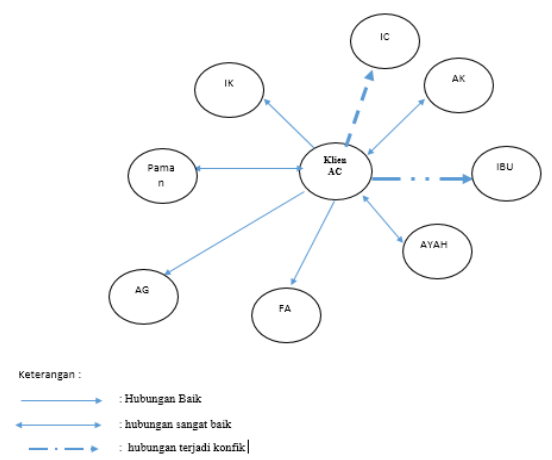

Gambar di atas menjelaskan AC dekat dengan bapaknya, berdasarakan hasil wawancara yang dilakukan oleh praktikan klien lebih terbuka dengan ayahnya ketika ingin sesuatu, sedangkan pada ibunya klien lebih tertutup karana ibu terkadang cepat marah ketika $\mathrm{AC}$ ingin berdikusi dengan ibunya. Dalam lingkungan teman sebaya klien AC lebih deka dengan IK terkadang AC bercerita tentang kendal-kendala yang didapatkan AC.

AC yang menceritakan pengalaman masalalu klien yang kurang baik dan menyenangkan . hal yang paling menyenangkan dilakukan oleh klien AC adalah pernah menjadi pemain inti dalam tim sepak bola di sekolahnya dan mendapatkan juara 2, klien pernah mendapatkan hadia diri orang tuanya. Namun hal yang paling menyedihkan klien pernah mengalami sakit sehingga tidak dapat bersekolah, dengan kondisi klien pernah merasa malu akibat mendapatkan ejekan dari temanya karna AC usia suda tidak sesuai dengan 
tingkat pendidikannya. Dalam pendidikan klien pernah dimarahi oleh guru dan mendapatkan hinaan dari temannya ketika klien AC mendapatkan angka merah dari hasil ujianya.

\section{Kondisi Awal HN}

Atachment merupakan pola asu yang positif perlu dilakukan oleh orang tua, karena denan melakukan kelekatan akan memoerbaiki tumbuh kembang anak. melakukan kelekatan kepada anak peran orang tua sangat menting karena orang tua sebagai obyek utama. Dalam melakukan attachment dengan anak tindakan yang dilakukan orang tua salah satunya dengan mengajar anak ketika anak tidak tahu untuk melakukan kegiatan yang perlu pendampingan dari keluarga. Orang tua memberikan attachment kepada anak akan meningkatkan pemenuhan kebutuhan psikologis anak, hal yang perlu diukur dari orang tua dalam melihat attachment yang dilakukan orang tua untuk HN dapat dilihat tabel 1 sebagai berikut :

\section{Tabel 1 Kondisi Awal Attachment Orang Tua}

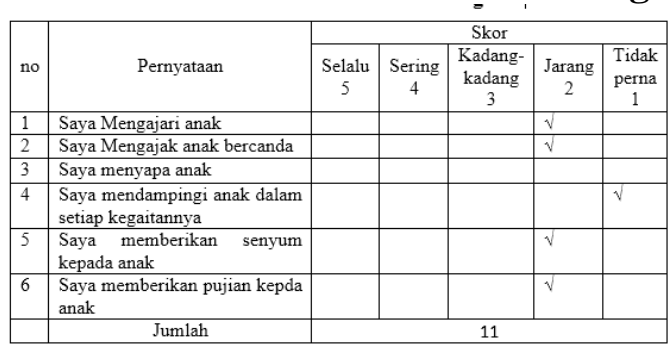

Tabel 1 di atas dapat diketahui total skor untuk attachmen awal subjek HN terhadap pemenuhan kebutuhan psikologisnya yaitu sebesar 11, maka akan ditentukan skor total setiap responden kemudian dilanjutkan dengan menentukan range, banyak kelas serta interval untuk selanjutnya dibuat garis kontinum. Berikut ini perhitungan menurut Moh. Nazir (2005:380): Cara menghitung kriteria skor, yaitu:

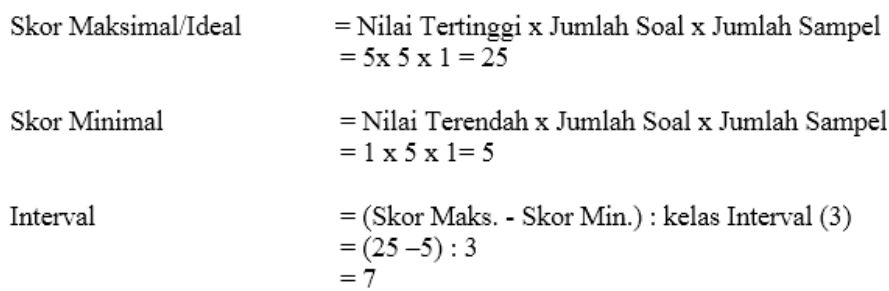
$=(25-5): 3$
$=7$

Interval

Berdasarkan hasil di atas, maka diperoleh gambaran tentang kondis awal attacment HN terhadap pemenuhan kebutuhan psikologisnya:

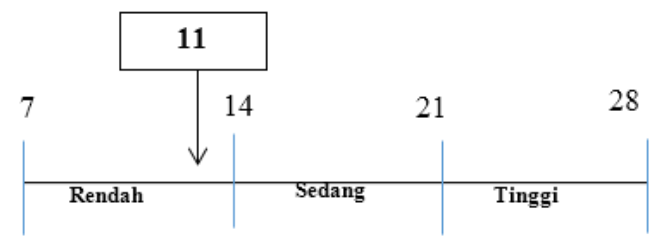

Garis Kontinum dalam attachment awal orang tua HN dalam memberikan kepada anak berada pada kategori rendah, hal ini menunjukkan bahwa orang tua kurang melakukan attaceman dengan HN. Dalam Attachment yang dilakukan anak dengan orang tua yang kurang sehingga anak tidak mmendapatkan kebutuhan pada usai dengan usianya dalam perkembangan. Selain menggunakan angket untuk mengetahui kondisi awal subyek HN peneliti menggunakan observasi dengan menggunakan telly berduasi tujuh jam dalam fase A, tujuan ini untuk mengamati prilaku attachmen yang dilakukan oleh $\mathrm{HN}$, berikut tabel 2: 
Tabel 2 Data Hasil Pengukuran Dan Pengamatan Prilaku Orang Tua Kondisi Awal Attachm en Subyek HN

\begin{tabular}{|l|c|c|c|c|c|}
\hline \multicolumn{1}{|c|}{ Perlakuan } & $\mathbf{1}$ & $\mathbf{2}$ & $\mathbf{3}$ & $\mathbf{4}$ & $\mathbf{5}$ \\
\hline Pujian & 1 & 1 & 1 & 2 & 2 \\
\hline Mendampingi anak & 1 & 1 & 1 & 1 & 2 \\
\hline tersenyum & 1 & 2 & 1 & 1 & 1 \\
\hline
\end{tabular}

Berdasarkan tabel 2 dapat disimpulkan nilai prilaku attacmenrt yang dilakukan orang tua khususnya pada fase A terjadi prilaku memberikan pujian, mendampingi anak, dan tersenyum. Untuk mendapatkan gambaran dalam setiap peningkatan garis dapat dilihat dalam grafik yang mengukur fase A yang akan menjelaskan kondisi awal sebgai berikut :

\section{Grafik 1 Data Hasil Pengamatan dan Pengukuran}

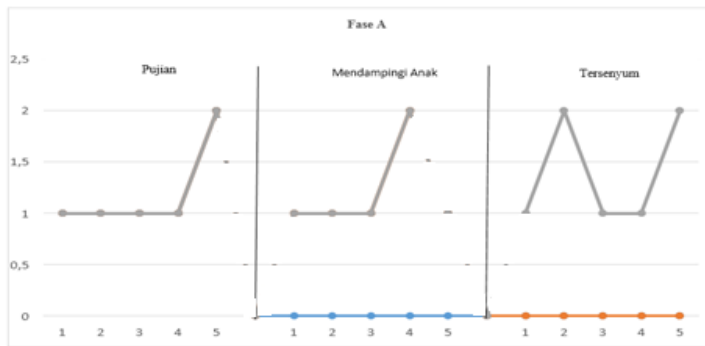

Grafik 1 dapat di simpulkan terlihat pada pertemuan pertaman dalam memberikan priku 1 dan terjadi peningkatan kegiatan pada perlakuan hari ke lima yaitu 2. Kemudian pada perlakuan mendampingi anak juga terjadi peningkatan pada hari pertaman berjumlah 1 dan meningkat pada hari kedua dengan berjumlah 2 dan pada perlakuan memberikan senyuman kepada anak terjadi penurunan dimana pada perlakukan pertemuan hari kedua dengan berjumlah 2 menunurun dihari kelima dengan berjumlah 1, dalam hal ini dapat disimpulkan perlakuan attachment yang dilakukan orang tua masi kurang karena orang tua belum memhami cara memberikan attachment kepada anak dan kendala orang tua yang kurang memahami prilaku pola asuh untuk anak usia 12 tahun dalam melakukan kelekatan.

\section{Kondisi Psikologis Klien HN}

Kebutuhan psikologis dalam masa perkembangan anak perlu untuk tumbuh kembang anak, kebutuhan psikologis yang tidak terpenuhi akan timbul persanaan kecewa atau rasa prustasi yang terjadi pada anak yang kaan berdampak pada perkembangan anak ketika desawa. Orang tua yang berperan dalam melakukan attacmen dengan anak yang memiliki perngaruh dalam peningkatan kebuthan psikologis melakukan dampingan kepada anak karna dengan melakukan dampingan dengan anak akan merasa mendapatkan perlindungan dari orang dan mendapatkan kasi sanyang karna attacment yang dilakukan oleh orang tua akan berpengaruh peningkatkan kebutuhan psikologis. Berikut tabel yang akan membahas kondisi psikologis anak awal subyek HN sebagai berikut :

Tabel 3 Pemenuhan Psikologis Kondis Awal Subyek HN

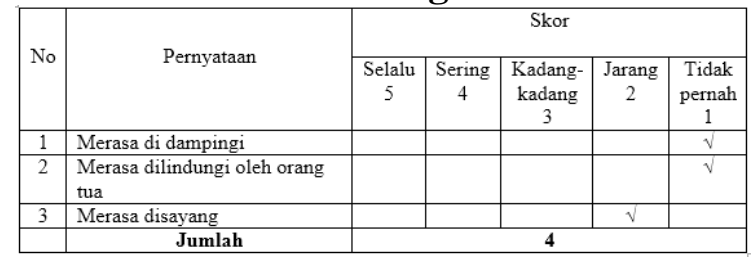


Tabel 3 di atas dapat diketahui total skor kondisi subjek HN kondis awal psikologis sebesar 44, maka akan ditentukan skor total setiap responden kemudian dilanjutkan dengan menentukan range, banyak kelas serta interval untuk selanjutnya dibuat garis kontinum. Berikut ini perhitungan menurut Moh. Nazir (2005:380), cara menghitung kriteria skor, yaitu:

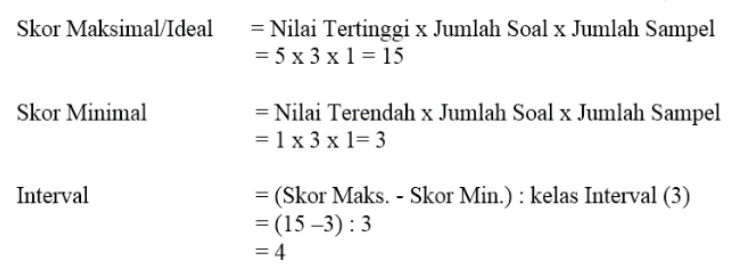

Berdasarkan hasil di atas, maka diperoleh gambaran tentang gambaran kondisi psikologis HN terhadap pemenuhan kebutuhan psikologisnya:

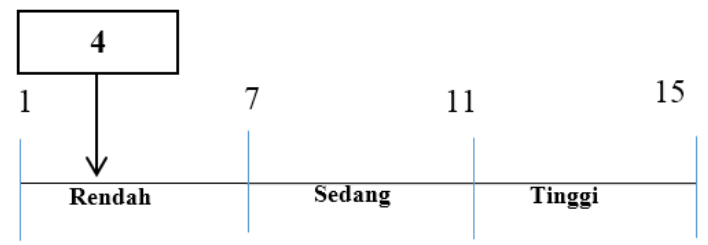

Garis Kontinum dalam kondisi psikologis subjek HN dalam dalam kondisi awal psikologis berada dalam kategori rendah, hal ini menunjukkan bahwa orang tua kurang memberikan pemenuhan kebutuhan psikologis anak yang dirasakan oleh anak. kondisi yang dirasakan anak merasa tidak mendapatkan kasi sayang dari orang tua sehingga hal ini menjadi faktor anak tidak merasakan kelekatan dari anak.

\section{Proses ABFT Subyek HN}

Pemberian interveni dilakukan selama 7 hari berdasarkan tahap-tapap dlam intervensi ABFT. tujuan dalam pelaksanaan terapi agar aggota keluarga membutuhkan kesadaran masing-masing yang mengalami masalah kelekatan antara keluarga dan anak. kegiatan ini memberika pehaman terhadap anggota keluarga agar dapat meningkatkan attacmen. adapun 5 langka yang dilakukan oleh peneliti dalam tahap ABFT sebagai berikut:

1. Tugas Membentuk Kembali Hubugan Anak dan Orang Tua
a. Memahami Kesalahan Serta Presepsi Salah Antara Keluarga
b. Tahap membangun kehangatan dan keeratan hubungan anak dan keluarga
c. Tahap membangun kehangatan dan keeratan hubungan anak dan keluarga

2. Tugas Membangun Kerjasama dengan Anak
a. Menjalin kerja sama dengan $\mathrm{HN}$
b. Memberikan Pemahaman Tentang Tujuan Terapi
c. identifikasi Kekuatan HN
d. Pengukapan Masalah yang di Alami HN
e. Tugas Yang Akan Dilaksanakan HN

\section{Tugas Membangun Kerjasama dengan Orang Tua}

Tujuan dalam kegiatan ini mendorong keluarga mengungkapkan keluhan dan harapan-harapan serta keinginan yang akan di capai terhadap kedua orang. Keudian Tahap ini peneliti membuka percakapan, menurut perlakuan yang dilakukan oleh ibunya HN terkadang malas ketika ibu meminta bantuan kepada $\mathrm{HN}$, kemuadian $\mathrm{HN}$ di angap malas dan menyepelehkan hasil kerjaan yang dilakukan oleh HN. Menjalin kerja sama dengan orang tua, merupakan tahap yang dilakukan oleh peneliti. kesapakan yang terjalin antara peneliti dengan orang tua yaitu memberikan perlakuan kepada HN ketikah HN melakukan kegiatan dan berhasil dalam melaksanakan tugasnya, sepertihalnya ketika HN belajar ibu memberikan 
dampingan ke HN dan memberikan senyuman ketika berhasil melaksanakan tugasnya, untuk kesepakatan tersebut berdasarkan permaslaahan yang di alami oleh keluarga dalam memberikan attachmen kepada HN dengan memberikan pemahaman kepada ibu HN akan meninkatkan potensi dalam melakukan pengasuhan yang baik kepada anak.

sesi ini terjadi untuk pengumkapan kesepakan permasalahan yang terjadi pada ibu HN. dalam tahap ini memberikan kesadaran kepada orang tua bahwa selama ini yang dilakukan dengan anak akan berdampak negatif dalam pemenuhan psikologis anak. ibu sadar dengan memarahi anak merupakan prilaku yang salah untuk anak dan tidak menyalahkan anak ketika melakukan kesalahan.

\section{Tugas Kelekatan (the attachment ask)}

Pada sesi ini merupakan proses penyadaraan pada ibu HN tentang tugas dan perannya masing-masing, yang lebih utama adanya pemahaman bersama tentang dan faktor penyebab terjadinya masalah pada klien HN. Tahap ini di ikuti oleh ibu dan klien HN ini di awali dengan penjelasan dari peneliti tentang hasil yang suda di capai menurut pengalaman peneliti. menurut penelitian HN suda menggukapkan permasalahan dan keluhan harapan-harapan terhadap orang tua agar dapat meluangkan waktunya untuk bersama $\mathrm{HN}$ dan melakukan kegiatan yang berkaitan dengan peningkatan atacmen terhadap keluarga. pada sesi ini diharapkan agar keluarga klien $\mathrm{HN}$ dapat saling memhami dan memenuhi masing-masing kebutuhan. Peneliti memberikan kesempatan kepada HN untuk menyampaikan kepada orang tua bagaimana harapan terhadap anak. sehingga saling memenuhi harapan dan keginginan yang akan di jalankan oleh orang tua.

Penelitian memberikan penjelasan dan masukan kepada orang tua kepada ibu bahwa perkembangan anak sesuai dengan kebutuhan yang ingin dicapai. bentuk tingka laku lekat pada orang tua harus di tampilkan, dapat berupa sikap yang akan mempertahankan komunikas, memberikan kepercayaan dalam meninkatkan attacment untuk pemenuhan kebuthan psikologis dan peran ibu sangat penting dalam menigkatkan kelekatan karena orang tua sebagai pengasuh yang akan memberikan pengasuhan dengan baik.

Ibu HN menyadari jika selama ini pada dirinya kurang memberikan pengasuhan yang tepat, sehingga ibu HN akan mengusahan melakukan implementasi mengenai atacman dalam memberikan pengasuhan kepada klien HN, terutama akan melakukan pendampingan kepada anak, memberikan pujian dan kasi sayang untuk HN, dalam kegiatan ini Ibu HN memberikan perlakukan kepada HN sesuai dengan kesepakatan yang suda disepakati.

Iahap berikutnya peneliti memberikan penjelasan kedapa ibu menganai manfaat ketika melakukan attachment kepada anak. masukan yang diberikan kepada ibu bahwa perkembangan anak usia HN masi membutuhkan attachmen dalam pemenuhan psikologisnya. bentuk tingka laku lekat yang akan dilakukan oleh orang tua harus ditampilkan, merupakan sikap yang akan di pertahankan untuk selalu memberikan pujian, kasi sayang dan mendampingi anak sesuai dengan kegiatan yang berlangsung, peran ibu $\mathrm{HN}$ yang akan menjaga kelekatan kepada anak dapat bermanfaat memberikan rasa aman kepada anak, akan meningkatkan pemenuhan kebutuhan psikologis anak dan $\mathrm{HN}$ akan merasa mendapatkan perhatian.

Kesadaran dari ibu menyadari jika selama ini yang dilakukan oleh ibu kepada anak adalah kesalahan dalam pegasuhan. pikiran ibu HN yang salah dapat memberikan perubahan tapi tidak ada dukungan dari orang ibu.

\section{Tugas Peningkatan Kopetensi}

Penelitian melakukan konsultasi terhadap keluarga terdekatnya baik tetangga maupun orang yang diangap berpengaruh dalam melakukan observsi mengenai perlakukan ABFT. 
orang tersebut adalah orang yang memberikan pengaruh kepada keluarga klien HN dalam memberikan masukan dan edukasi mengenai atacmen

Tahap ini di akhiri dengan kesepakatan bersama untuk saling memantau pekerkembangan keluarga klien $\mathrm{HN}$ dalam meningkatkan hubungan attacmen kepada keluarga. peneliti akan kerja sama dengan observer dalam melakukan observasi perkembangan yang dilakukan ibu .

Tahap ini dengan kesapakatan bersama saling memantau perkembangan $\mathrm{HN}$, peneliti juga menyampaikan akan melakukan observasi pengamatan langsug terahadap HN ketika orang tua memberikan perlakukan yang di sepakati sesuai dengan kebutuhan dan permasalahan, peneliti akan meminta kerjasama dengan tetangnya untuk mendapatkan data akurat perlakuan-perlakuan yang dilakukan oleh orang tua.

\section{Pengaruh ABFT Terhadap Harga Diri Subyak HN}

1. Pengaruh ABFT dalam Rasa Aman

Pengaruh ABFT dalam memberikan rasa aman merupakan tidakan yang dilakukan oleh orang tua dalam meningkatkan attacmen antara orang tua dan anak, dalam hal ini orang tua melakukan perlakuaan dalam memberikan rasa aman kepada klien HN antara lain mendampngi anak dalam belajar, mendampigi anak ketika bermain dan pada saat berada di lingkungan teman sebayanya, dengan memberikan rasa aman kepada anak akan merasakan.

Pemenuhan keputuhan psikologis akan terpenuhi, sehingga anak merasa mendapat perhatian dari orang tua. Tabel 5 data hasil pengukuran dan pengamatan prilaku dalam memberikan rasa aman kepada anak, sebagai berikut:

Tabel 5 Data Hasil Pengukuran dan Pengamatan Rasa Aman Subyek HN

\begin{tabular}{|c|c|c|c|c|c|c|c|c|c|c|c|c|c|c|c|}
\hline Perlakuan & \multicolumn{4}{|c|}{ Fase $\mathbf{A}$} & \multicolumn{5}{c|}{ Intervensi B } & \multicolumn{5}{c|}{ Hasil A2 } \\
\cline { 2 - 16 } & 1 & 2 & 3 & 4 & 5 & 6 & 7 & 8 & 9 & 10 & 11 & 12 & 13 & 14 & 15 \\
\hline Rasa aman & 1 & 1 & 1 & 1 & 2 & 3 & 3 & 5 & 5 & 5 & 4 & 5 & 5 & 7 & 8 \\
\hline
\end{tabular}

Berdasarkan tabe 5 di atas dapat di simpulkan bahwa rata-rata prilaku attacmen yang dilakukan oleh orang tua dalam pengaruh ABFT dalam rasa aman dapat dilihat terjadi penngkatan pada fase intervensi terjadi peningkatan perlakuaun yang dilakukan oleh orang tua $\mathrm{HN}$ smencapai 5 perlakuan pada saat sesi 10, sedangkan pada fase hasil kembali terjadi peningkatan perlakuan yaitu perlakuan. hal ini terjadi karena orang tua suda mengetahu kapan memberikan perlakukan dalam memberikan attacmen kepada anak. Untuk lebih jelasnya dapat di lihat terjadinya peningkatan perlakukan melalui grafik 2 sebagai berikut :

\section{Grafik 2 Perilakuan orang tua Memberikan Harga Diri Subyek HN}

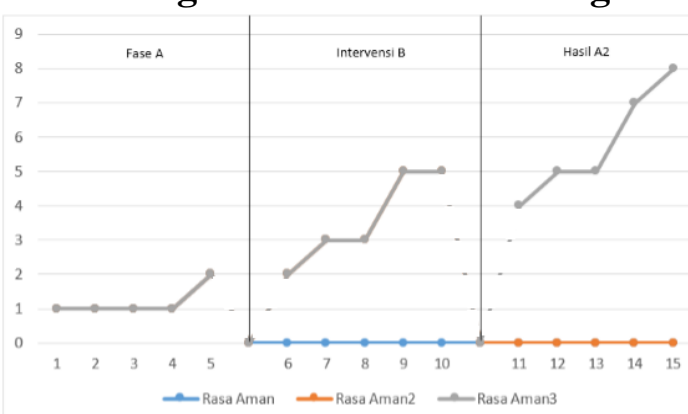

2. Pengaruh ABFT Terhadap Kasi Sayang Subyek HN

Kasi sayang merupakan salah satu bentuk attachment yang dilakukan oleh ibu, dengan memberikan kasi sayang kepada anak akan meningkatkan kebutuhan psikolologis anak. Perlakuan kasi sayang dilakukan oleh orang tua akan meningkatkan kelekatan kepada anak, kemudian orang tua memhami apa yang menjadi kekeurangan anak dan hal yang di inginkan anak. Perlakuaan kasi sayang yang dilakukan oleh orang tua yang dapat meningkatkan pemenuhan psikologis anak yang akan merasa mendapatkan perhatian dari 
orang tuanya, tabel 5 menjelaskan data pengukran dan preilakukuan attacmen Subjek HN, dapat di liahat sebagai berikut :

\begin{tabular}{|c|c|c|c|c|c|c|c|c|c|c|c|c|c|c|c|c|}
\hline \multirow{2}{*}{ No } & \multirow{2}{*}{ Perlakuan } & \multicolumn{5}{|c|}{ Base A } & \multicolumn{5}{|c|}{ intervensi B } & \multicolumn{5}{|c|}{ Hasil A2 } \\
\hline & & 1 & 2 & 3 & 4 & 5 & 6 & 7 & 8 & 9 & 10 & 11 & 12 & 13 & 14 & 15 \\
\hline 1 & Pujian & 1 & 1 & 1 & 2 & 2 & 3 & 3 & 4 & 4 & 5 & 4 & 4 & 5 & 7 & 8 \\
\hline 2 & $\begin{array}{l}\text { Mendampingi } \\
\text { Anak }\end{array}$ & 1 & 1 & 1 & 1 & 2 & 3 & 3 & 5 & 5 & 5 & 4 & 5 & 5 & 7 & 8 \\
\hline 3 & Membelai & 1 & 2 & 1 & 1 & 2 & 3 & 3 & 4 & 6 & 6 & 5 & 5 & 6 & 8 & 8 \\
\hline
\end{tabular}

Di bawah ini, data hasil pengukuran penamatan mengenai attacment subjek HN dalam penigkatan kebutuhan psikologis anak sebagai berikut:

Grafik 4 Data Hasil Pengamatan dan Pengukuran Prilaku Attachmant Subjek HN

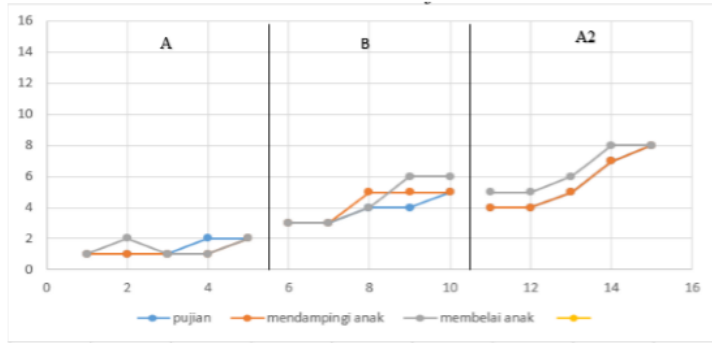

\section{Perkebangan Attachmen Setelah Intervensi}

Orang tua yang memberikan attachment kepada anak akan meningkatkan kebutuhan psikologis anak sehingga terpenuhinya kebutuhan tumbuh kembang anak. hasil intervensi yang dilakukan ABFT dapat meningkatkan prilaku orang tua untuk melakukan attachmen yang menjadi salah satu hal yang yang dilakukan orang, intervensi yang dilakukan untuk orang tua $\mathrm{HN}$ menjadi kesadaran bagi ibu untuk terus meningkatkan kelekatan ke anakya, berikut tabel 6 pertanyaan mengenai prilaku attachment yang dilakukan orang tua sebagai:

Tabel 6 Data Hasil Pengukuran dan Pengamatan Attachment Subyek Orang HN

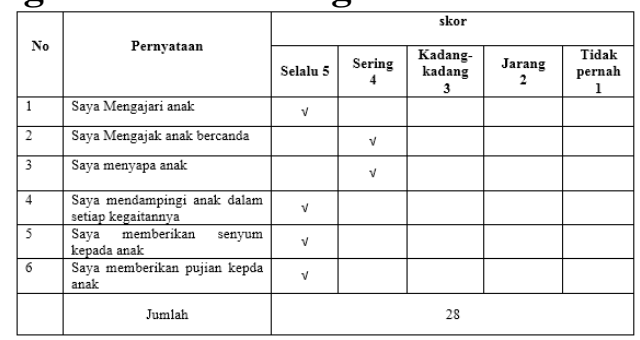

Tabel 6 di atas dapat diketahui total skor untuk perkembangan attachemet setelah perlakukan pemenuhan kebutuhan psikologisnya yaitu sebesar 28, maka akan ditentukan skor total setiap responden kemudian dilanjutkan dengan menentukan range, banyak kelas serta interval untuk selanjutnya dibuat garis kontinum. Berikut ini perhitungan menurut Moh. Nazir (2005:380), cara menghitung kriteria skor, yaitu:

$\begin{array}{ll}\text { Skor Maksimal/Ideal } & =\text { Nilai Tertinggi } \times \text { Jumlah Soal } \times \text { Jumlah Sampel } \\ & =5 \times 6 \times 1=30 \\ \text { Skor Minimal } & =\text { Nilai Terendah } \times \text { Jumlah Soal } \times \text { Jumlah Sampel } \\ & =1 \times 6 \times 1=6 \\ \text { Interval } & =(\text { Skor Maks. }- \text { Skor Min. }): \text { kelas Interval (3) } \\ & =(30-6): 3 \\ & =8\end{array}$

Berdasarkan hasil di atas, maka diperoleh gambaran tentang pemberian attachment subyek HN terhadap pemenuhan kebutuhan psikologisnya:

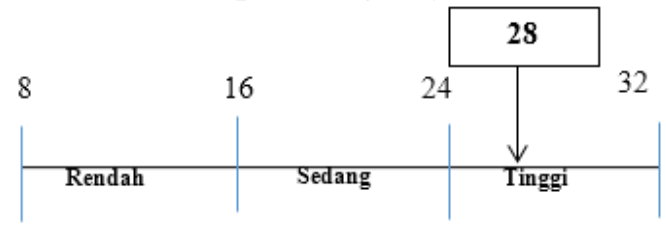


Garis Kontinum perkembangan attachmen yang dilakukan oleh ibu HN dengan jumlah skor 28, hal ini mengambarakan orang tua mampu memberikan attachmen kepada anak. Orang tua yang memberikan attacmen kepada anak merupakan pengaruh dari terapi yang diberikan kepada keluarga. Keluarga yang suda mampu memberikan attachmen kepada anak sehinggah hubungan orang tua dengan anak dapat terjadi kelekatan.

\section{Perkembangan Klien HN Setelah Intervensi}

Prilaku ibu yang melakukan attachment kepada anak berpengaruh pada peningkatan psikologis anak yang menjadi kebutuhan tumbuh kembang anak. orang tua yang melakukan attacmen kepada anak akan merasakan prilaku orang tua bahawa melakukan upaya kelekatan kepada anak. Tindakan yang dilakukan orang tua akan berdampak positif kepada anak sehingga anak juga merasakan kasi sayang orang tua, berikut tabel 4,33 yang akan memberikan gambaran mengenai perkembangan psikolofgis setelah mendapatkan intervensi dari orang tua:

\section{Tabel 7 Kondisi Perkembangan Psikologis Subyek HN}

\begin{tabular}{|c|c|c|c|c|c|c|}
\hline \multirow[b]{2}{*}{ no } & \multirow[b]{2}{*}{ Pernyataan } & \multicolumn{5}{|c|}{ Skor } \\
\hline & & $\begin{array}{c}\text { Selalu } \\
5\end{array}$ & $\begin{array}{c}\text { Sering } \\
4\end{array}$ & $\begin{array}{c}\text { Kadang- } \\
\text { kadang } \\
3\end{array}$ & $\begin{array}{c}\text { Jarang } \\
2\end{array}$ & $\begin{array}{c}\text { Tidak } \\
\text { pernah } \\
1\end{array}$ \\
\hline 1 & Merasa di dampingi & $\sqrt{ }$ & & & & \\
\hline 2 & $\begin{array}{l}\text { Merasa dilindungi } \\
\text { oleh orang tua }\end{array}$ & & $v$ & & & \\
\hline 3 & Merasa disayang & $\sqrt{ }$ & & & & \\
\hline & Jumlah & & & 14 & & \\
\hline
\end{tabular}

Tabel 7 di atas dapat diketahui total skor untuk ABFT Klien HN terhadap pemenuhan kebutuhan psikologisnya yaitu sebesar 44, maka akan ditentukan skor total setiap responden kemudian dilanjutkan dengan menentukan range, banyak kelas serta interval untuk selanjutnya dibuat garis kontinum. Berikut ini perhitungan menurut Moh. Nazir (2005:380):

Cara menghitung kriteria skor, yaitu:

$$
\begin{array}{ll}
\text { Skor Maksimal/Ideal } & =\text { Nilai Tertinggi } \times \text { Jumlah Soal } \times \text { Jumlah Sampel } \\
& =5 \times 3 \times 1=15 \\
\text { Skor Minimal } & =\text { Nilai Terendah } \times \text { Jumlah Soal } \times \text { Jumlah Sampel } \\
& =1 \times 3 \times 1=3 \\
\text { Interval } & =(\text { Skor Maks. }- \text { Skor Min. }): \text { kelas Interval }(3) \\
& =(15-3): 3 \\
& =4
\end{array}
$$

Berdasarkan hasil di atas, maka diperoleh gambaran tentang ABFT Klien AC terhadap pemenuhan kebutuhan psikologisnya:

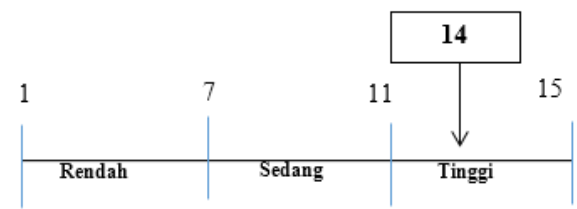

Garis Kontinum mengenai perkembangan psikologis HN setelah intervensi berada pada skor 14. Garis kontinum tersebut menggambarkan bahwa terpenuhinya kebutuhan psikologis HN, perlakuan yang dilakukan ibu dirasakan oleh HN ketika ibu mendampingi HN pada saat meakukan kegiatan dan mendapatkan kasi sayang dari ibunya, sehingga HN merasa bahagia ketika ibunya melakukan hal tersebut. Selain melakukan peneliti juga melakukan wawancara untuk mengetahu secara mendalam, berikut pernyataan dari HN.

\section{Kondisi Awal Subyek AC}

Melakukan attachment dengan anak tindakan yang dilakukan orang tua salah satunya dengan mengajar anak ketika anak tidak tahu untuk melakukan kegiatan yang perlu pendampingan dari keluarga. Orang tua memberikan attachment kepada anak akan meningkatkan pemenuhan kebutuhan psikologis anak, hal yang perlu diukur dari orang tua 
dalam melihat attachment yang dilakukan orang tua untuk HN dapat dilihat tabel 8 sebagai berikut:

\section{Tabel 8 Kondis Awal Attachmen Klien AC}

\begin{tabular}{|c|c|c|c|c|c|c|}
\hline \multirow[b]{2}{*}{ no } & \multirow[b]{2}{*}{ Pernyataan } & \multicolumn{5}{|c|}{ Skor } \\
\hline & & $\begin{array}{c}\text { Selalu } \\
5\end{array}$ & $\begin{array}{c}\text { Sering } \\
4\end{array}$ & $\begin{array}{c}\text { Kadang-- } \\
\text { kadang } \\
3\end{array}$ & $\begin{array}{c}\text { Jarang } \\
2\end{array}$ & $\begin{array}{c}\text { Tidak } \\
\text { pernah } 1\end{array}$ \\
\hline 1 & $\begin{array}{l}\text { Saya Mengajari anak } \\
\end{array}$ & & & & $\mathrm{v}$ & \\
\hline 2 & Saya Mengajak anak bercanda & & & & $v$ & \\
\hline 3 & Saya menyapa anak & & & & & $\mathrm{v}$ \\
\hline 4 & $\begin{array}{l}\text { Saya mendampingi anak dalam } \\
\text { setiap kegaitannya }\end{array}$ & & & & $\mathrm{v}$ & \\
\hline 5 & $\begin{array}{l}\text { Saya memberikan senyum } \\
\text { kepada anak }\end{array}$ & & & & & $\mathrm{v}$ \\
\hline 6 & $\begin{array}{l}\begin{array}{l}\text { Saya memberikan } \\
\text { kepda anak }\end{array} \\
\text { pujian }\end{array}$ & & & & v & \\
\hline & Jumlah & & & 10 & & \\
\hline
\end{tabular}

Tabel 8 atas dapat diketahui total skor kondisi awal attachment subjek HN 10, maka akan ditentukan skor total setiap responden kemudian dilanjutkan dengan menentukan range, banyak kelas serta interval untuk selanjutnya dibuat garis kontinum. Berikut ini perhitungan menurut Moh. Nazir (2005:380):

Cara menghitung kriteria skor, yaitu:

$$
\begin{array}{ll}
\text { Skor Maksimal/Ideal } & =\text { Nilai Tertinggi } \times \text { Jumlah Soal } \times \text { Jumlah Sampel } \\
& =5 \times 6 \times 1=30 \\
\text { Skor Minimal } & =\text { Nilai Terendah } \times \text { Jumlah Soal } \times \text { Jumlah Sampel } \\
& =1 \times 6 \times 1=6 \\
\text { Interval } & =(\text { Skor Maks. }- \text { Skor Min. }): \text { kelas Interval }(3) \\
& =(30-6): 3 \\
& =8
\end{array}
$$

Berdasarkan hasil di atas, maka diperoleh gambaran tentang ABFT Klien AC terhadap pemenuhan kebutuhan psikologisnya:

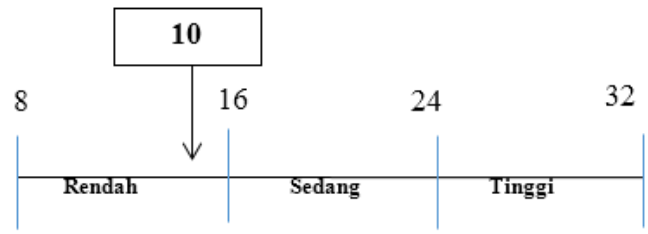

Garis Kontinum mengenai kondis awal attachment subyek AC menunjukkan kategori rendah, hal ini menggambarkan kondisi awal attachment untuk klien AC masi Kurang yang dilakukan oleh ibu, dalam kondisi ini $\mathrm{AC}$ akan berdampak negatif untuk perkembangan karena attachment yang berkaitan dalam kebutuhan pemunuhan kebutuhan psikologis tidak terpenuhi dalam tumbuh kembang anak

Selain menggunakan angket dalam penelitian ini melakukan observsi dengan menggunakan tely untuk melihat jumlah perlakuan awal orang tua dalam memberikan attachment kepada anak, apek yang di observasi adalah memberikan pujian kepada anak, mendampingi anak dan Membelai anak kepada anak. berikut tabel 9 :

Tabel 9 Data Perlakuan Orang Tua Subyek AC Pada Fase A

\begin{tabular}{|c|c|c|c|c|c|c|}
\hline \multirow{2}{*}{ no } & \multirow{2}{*}{ Perkaluan } & \multicolumn{5}{|c|}{ Fase A } \\
\cline { 3 - 7 } & Pujian & 1 & 2 & 3 & 4 & $\mathbf{5}$ \\
\hline 1 & 1 & 1 & 1 & 1 & 1 \\
\hline 2 & Mendampkingi anak & 1 & 1 & 1 & 2 & 2 \\
\hline 3 & Membelai anak & 1 & 1 & 1 & 2 & 2 \\
\hline
\end{tabular}

Tebel di atas menunjukan fase A sebelum terjadi perlakukan kondisi attachment sebelum mendapatkan perlakuan. Tabel mengambarkan orang tua kurang melakukan attacmen kepada anak, sehingga dapat katakan anak tidak mendapatkan attacment dari orang tua, untuk melihat peningkatan prilaku dapat dilihat pada: 


\section{Grafik 4 Data Hasil Perlakuan Orang Tua AC Pada Fase A}

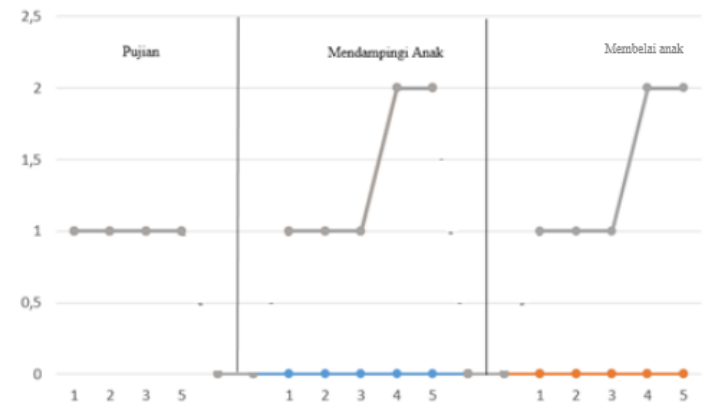

Berdasarkan grafik 4 di atas menjelaskan menjelakan kondisi attachment klien sebelum mendapatkan intervensi terapi ABFT, yang dilakukan observasi untuk melihat aspek pujian, mendampingi anak dan Membelai anak kepada anak. dalam aspek pujian terlihat dari batas atas kebawa mengalami kesamaan jumlah yaitu satu hal ini menunjukkan dalam satu hari orang tua melakukan satu kali memberikan pujian kepada Subyek AC. Pada aspek mendampingi anak jumlah perlakuan pada hari pertama adalah 1 dan mengalami peningkatan pada hari kelima yaitu berjumlah 2 dan aspek Membelai anak kepada an sama hal nya dengan jumlah di dihari pertama yaitu satu meningkat di hari ke lima dengan berjumlah satu. Hal ini menggambarkan terjadi meningkatan antar kondisi. Kurangnya prilaku attacmen yang di dapatkan oleh anak di sebabkan orang tua kurang percaya diri untuk melakukan attachment dan kurang mengetahui bagai mana pemberian attachmen secara efektif .

\section{Kondisi Awal Psikologis Subyek AC}

Anak yang mengalami permasalahan dalam kondis psikologis akan berpengarauh pada tumbuh kembangnya, kurangnya kasi sayang yang didapatkan kepada orang tua akan berpengaruh pada pertumbuhan psikologisnya. Dalam kondisi awal psikologis subyek AC masi kurang hal ini di sebabkan karena orang tua kurang memhami menganai kebutuhan psikologis anak. Lebih jelasnya dapat dilihat dari tabel 10 berikut ini :

\section{Tabel 10 Kondisi Psikologis Awal Subyek AC}

\begin{tabular}{|c|l|c|c|c|c|c|}
\hline \multirow{2}{*}{ no } & Pernyataan & $\begin{array}{c}\text { Selalu } \\
5\end{array}$ & $\begin{array}{c}\text { Sering } \\
4\end{array}$ & $\begin{array}{c}\text { Kadang- } \\
\text { kadang } \\
3\end{array}$ & $\begin{array}{c}\text { Jarang } \\
2\end{array}$ & $\begin{array}{c}\text { Tidak } \\
\text { perna } \\
1\end{array}$ \\
\hline 1 & $\begin{array}{l}\text { Merasa di } \\
\text { dampingi }\end{array}$ & & & & $v$ & \\
\hline 2 & $\begin{array}{l}\text { Merasa dilindungi } \\
\text { oleh orang tua }\end{array}$ & & & & $v$ & \\
\hline 3 & Merasa disayang & & & & & $v$ \\
\hline \multicolumn{5}{|c|}{ Jumlah } & \multicolumn{5}{|c|}{5} \\
\hline
\end{tabular}

Tabel 10 di atas dapat diketahui total skor untuk untuk kondis awal psikologis subyek AC sebesar 4, maka akan ditentukan skor total setiap responden kemudian dilanjutkan dengan menentukan range, banyak kelas serta interval untuk selanjutnya dibuat garis kontinum. Berikut ini perhitungan menurut Moh. Nazir (2005:380): Cara menghitung kriteria skor, yaitu:

$$
\begin{array}{ll}
\text { Skor Maksimal/Ideal } & =\text { Nilai Tertinggi } \times \text { Jumlah Soal } \times \text { Jumlah Sampel } \\
& =5 \times 3 \times 1=15 \\
\text { Skor Minimal } & =\text { Nilai Terendah } \times \text { Jumlah Soal } \times \text { Jumlah Sampel } \\
& =1 \times 3 \times 1=3 \\
& =(\text { Skor Maks. }- \text { Skor Min. }): \text { kelas Interval (3) } \\
\text { Interval } & =(15-3): 3 \\
& =4
\end{array}
$$


Garis Kontinum Pengaruh kondisi awa psikologis subyek AC menunjukka kategori redah, hal ini menggambarkan bahwa kondis psikologis AC mengalami masalah. Orang tua AC yang tidak memberikan pemenuhan kebutuhan psikologis AC karena belum mengatahui kebutuhan-kebutuhan dalam melakukan pengasuhan oleh anak. selain itu orang tua AC kurang percaya diri untuk melakukan kelekatan kepada anak dan belum mengetahui bagai mana waktu yang tempat untuk memberikan kelekatan kepada anak

\section{Pengaruh ABFT Terhadap Pemenuhan Psikologis}

Pemenuhan psikologis salah satunya adalah dengan meningkatkan harga diri anak, orang tua yang lekat dengan anak akan memberikan harga diri kepada anak untuk terpenuhinya kebutuhan pskologis. dengan terpenuhinya kebutuhan psikologis yang dilakukan oleh orang tua akan memberikan pengaruh dalam perkembangan psikologis yang diperlukan oleh anak bentuk harga diri yang diberikan oleh orang tua adalah dengan memberikan pujian ketika anak berhasil mencapai prestasi, berhasil mengerjakan tugasnya dan merubah prilakunya dengan baik, maka dampak yang akan anak dirasakan mendapatkan penghargaan dari keluarganya akan merada dihargai dan mendapatkan penerimaan dari keluarganya. berikut pada tabel 11 mengenai pujian yang dilakukan oleh orang tua untuk subjek AC sebagai berikut :

\section{Tabel 10 Data Hasil Pengukuran dan Pengamatan Prilaku Attachment perlakukan Orang Tua Subjek AC

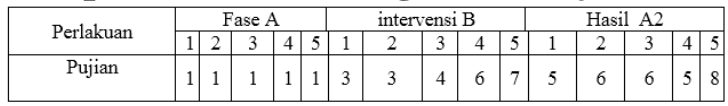

Berdasarkan tabel 10 dapat di simulkan bahwa rata-rata kemampuan orang tua dalam melakukan attacmen memberikan harga diri kepada klien AC terjadi peningkatan dari fase A ke fase intervensi, hal ini menunjukkan bahawa orang tua mampu memberikan attacmen kepada subjek AC. Peningkatan terjadi karena orang tua mendapatkan intervensi dan melakukan tahap-tahap intervensi dalam terapi ABFT sehigga orang tua mampu memberikan perlakuan Atachment khususnya harga diri. perlakuan orang tua memberikan harga diri kepada AC yaitu memberikan pujian kepada AC ketika melakukan hal yang positif, dengan memberikan akan meningatkan attacmen kepada AC. Perlakukan orang tua yang semakn menigkat menunjukkan bahwa orang tua memahami bagai mana memberikan attacmen kepada anak sehingga orang tua mengetahui fungsi attacmen dalam meningkatkan pemenuhan psikologis anak. Untuk lebih jelasnya dapat di lihat grafik 6 data hasil pengamatan pengukurang prilaku attacmen yang dilakukan orang tua sebagai berikut:

\section{Grafik 6 Data Hasil Pengamatan Dan Penguran Prilaku Attacmen Yang Dilakukan Orang Tua AC pujian}

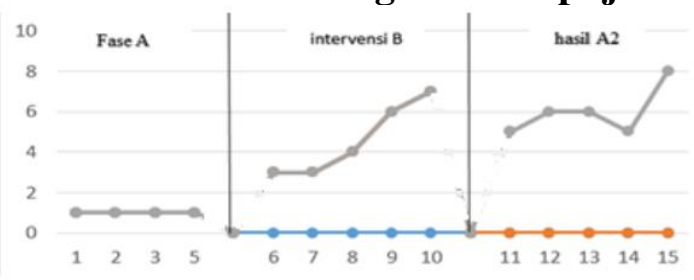

\section{Pengaruh ABFT Terhadap Rasa Aman (Mendampingi Anak)}

Rasa aman adalah dimana kondisi anak berada dalam lindungan ancaman yang tidak menutup kemungkinan akan terjadi pada anak. Orang tua memberikan rasa aman akan terbentuknya kelekatan pada anak. Terkadang orang tua yang lupa memberikan rasa aman yang merupakan hal yang penting dalam kehidupan anak dan rasa aman muncul dalam diri kehidupan anak, bila orang tua terlibat secara emosinal dan renfontif mengenai kebutuhankebutuhan anak maka orang tua dengan penuh insiatif selalu bertindak memberikan rasa 
aman kepada anak. pada penganagan subjek AC orang tua memberka perlakuan dalam melakukan rasa aman kepada anak namun pada tahap awal orang tua belum mengetahui bagai mana cara mengimplementasiakan bentuk-bentuk rasa aman yang akan di berikan kepada AC berikut tabel 11 yang akan menjelaskan data hasilpengukuan prilaku attacmen dalam pemenuhan kebutuhan psikologis:

Tabel 11 Data Hasil Pengamatan Pengukuran Orang Tua Subjek AC dalam Mendampingi Anak

\begin{tabular}{|c|c|c|c|c|c|c|c|c|c|c|c|c|c|c|c|c|}
\hline \multirow{2}{*}{ Perlakukan } & \multicolumn{4}{|c|}{ Fase A } & \multicolumn{6}{|c|}{ Intervensi B } & \multicolumn{6}{c|}{ Hasil A2 } \\
\cline { 2 - 15 } \\
\hline $\begin{array}{l}\text { Mendampingi } \\
\text { anak }\end{array}$ & 1 & 2 & 1 & 1 & 2 & 2 & 4 & 4 & 6 & 5 & 7 & 6 & 6 & 5 & 6 & 7 \\
\hline
\end{tabular}

Berdasarkan tabel di atas dapat di simpulkan pengamatan pengukuran klien AC dalam memberikan mendampingi kepada anak, terlihat terjadi perubahan pada setiap fase. peningkatan terjadi pada fase intervensi dalam sesi 10 , hal ini orang tua mampu memberikan rasa aman kepada AC ketika AC bermain bersama temannya dan belajar berasama orang tua ikut mendampingi anak. kemudian dari intervensi menunju hasil terjadi peningkatan kepada perlakukan yang dilakukan oleh orang tua, hal ini menunjukk orang tua semakin mampu memberikan atacmen kepada anak dalam yang memiliki pengaruh dalam peningkatan kebutuhan pasikologisnya. untuk lebih jelasnya dapat di lihat grafik 7 sebagai berikut :

Grafik 7 Data Hasil Pengamatan dan Pengukuran Subyek AC dalam Perlakuan Orang Tua Melakukan Attachment

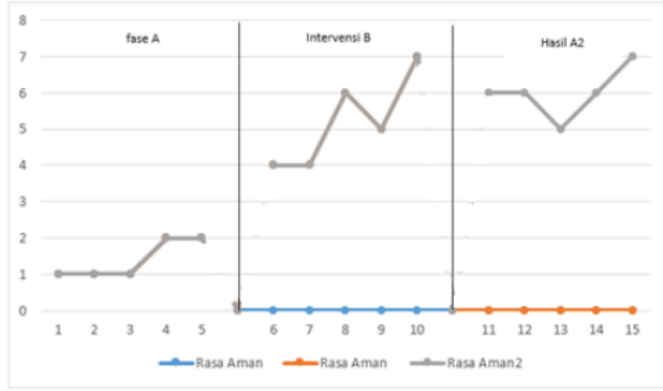

\section{Pengaruh ABFT Terhadap Kasi Sayang}

Orang tua yang menjadi sosok yang sangat berperan untuk melakukan pemenuhan kebutuhan hak anak. orang tua di harapkan mampu memberikan kasi sayang yang sifatnya memberikan kehangatan, kebutuhan rasa dierima dan menamankan rasa aman, karena kasi sayang berguna untuk mengembangkan kepribadian, menanamkan kedisplinan, memberikan arahan dan dorongan agar anak berani dalam menghadapi kebutuhannya. Hal yang terjadi pada subjek AC kurang mendapatkan perlakuan dalam bentuk kasi sayang sehingga masi terlihat rendah. Terjadinya kurang prilaku karena orang AC belum memahami bagaimana memberikan perlakuan kasi sayang kepada anak. berikut tabel data hasil pengamatan Rasa Aman yang dilakukan oleh subyek sebagai berikut:

Tabel 10 Data Hasil Pengukuran dan Pengamatan Prilaku Membelai Attacmen orang tua Subjek AC

\begin{tabular}{|c|c|c|c|c|c|c|c|c|c|c|c|c|c|c|c|}
\hline \multirow{2}{*}{ Perlakuan } & \multicolumn{9}{|c|}{ Fase A } & \multicolumn{1}{|c|}{ Intervensi B } & \multicolumn{6}{|c|}{ A2 } \\
\cline { 2 - 16 } & 1 & 2 & 3 & 4 & 5 & 6 & 7 & 8 & 9 & 10 & 11 & 12 & 3 & 14 & 15 \\
\hline $\begin{array}{c}\text { Membelai } \\
\text { anak) }\end{array}$ & 1 & 1 & 1 & 2 & 2 & 4 & 4 & 6 & 6 & 7 & 8 & 6 & 7 & 7 & 8 \\
\hline
\end{tabular}

Berdasarkan tabel di atas dapat di simpulkan terjadi perubahan peningkatan pada fase A ke fase intervensi. Hal ini terjadi kerena orang tua subejek HN memahami bagaimana cara memberikan attacmen dalam meninigkatkan kebutuhan psikologis anak. Orang tua yang mengetahui pemberian attacmen kepada anak ketika mendampingi anak belajar dan memberikan senyuman kepada anak yang berhasil menyelesaikan dengan baik, dalam tahap intervensi orang tua mengatahui cara waktu yang tepat memberikan senyuman kepada anak 
dan menyadari bahawa dengan memberikan kasi sayang kepada anak akan meningkatkan pemenuhan psikologis anak. berikut grafik 8 yang akan menjelaskan data hasil pengamatan dan mengukuran prilaku attacment orang tua subjek AC:

Grafik 11 Data Hasil Pengamatan dan Mengukuran Prilaku Attacment dalam

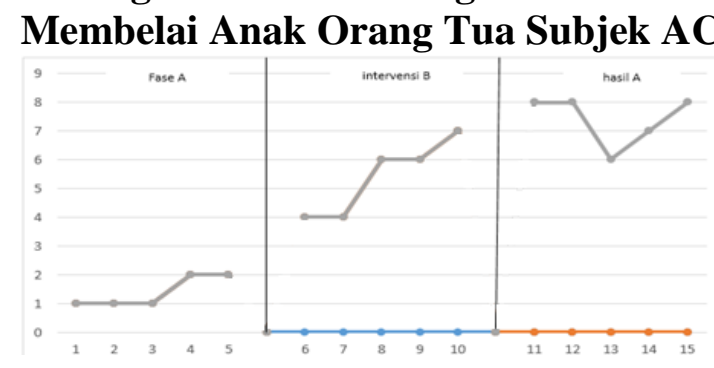

\section{Pembahasan dan Analisis}

Analisis data dalam penelitian ini bertujuan untuk mengetahui efek atau pengaruh dalam atacmant dalam peningkatan kebutuhan psiologis anak. analisis yang di gunakan dalam penelitian ini inspektif visual. Analisis ini dilakukan melalui pengamatan secara langsung terhadap data yang telah ditampilkan dalam grafik. Ada dua cara untuk melakukan analisis inspeksi visual. yaitu analisis dalam kondisi dan analisis antar kondisi. Komponen yang terdapat dalam analisis dalam kondisi meliputi panjang kondisi, kecenderungan arah, jejak data, level stabilitas dan rentang, perubahan level. Sedangkan komponen yang ada dalam analisis antar kondisi meliputi jumlah variabel yang diubah, perubahan kecenderungan arah dan efeknya, perubahan stabilitas, perubahan level, dan data overlap.

Data hasil penelitian desian subyek tunggal ini disajikan dalam bentuk grafik. Grafik ini bertujuan untuk melihat data hasil pengukuran dan pengamatan perilaku sasaran keluarga AC dalam suatu kondisi yang berbeda yakni fase baseline, intervensi, dan hasil. Peneliti menyajikan grafik yang menunjukkan hasil pengukuran dan pengamatan terhadap perilaku memebrikan pujian, melindungi anak, dan Membelai anak, hal ini untuk melaihat perbandingan yang akan lebih jelas jika terjadi peningkatan perlakuan yang dilakukan oleh ibi HN. Indikator yang diukur hanya frekuensi sebelum, selama, dan sesudah intervensi

Hasil pengukuran dan pengamatan terhadap attachment, yaitu memberiakn pujian, mendampingi anak dan memberikan senyuman dengan model A-B-A dalam 15 sesi, dapat di lihat dalam tabel berikut ini :

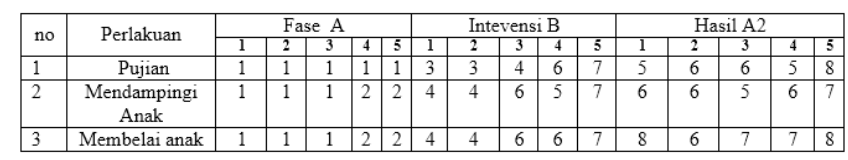

Tabel di atas menunjukkan data Hasil pengukuran dan pengamatan attchmen yang dilakukan orang tua $\mathrm{AC}$, tabel tersebut dalam pola A-B-A yang menunjukkan terjadinya perubahan peningkatan perlakuan yang dilakukan oleh HN. kemudian di bawah ini, merupakan data hasil pengukuran penamatan mengenai Attachment subjek AC penigkatan kebutuhan psikologis anak dalam melakukan attachmen dari orang tua berikut, grafik 12 sebagai berikut yang akan memberikan gambaran terjadi peningkatan garis perlakuan

Grafik 12 Data Hasil Pengamatan dan Pengukuran Prilaku Attachmant Subyek Klien AC 


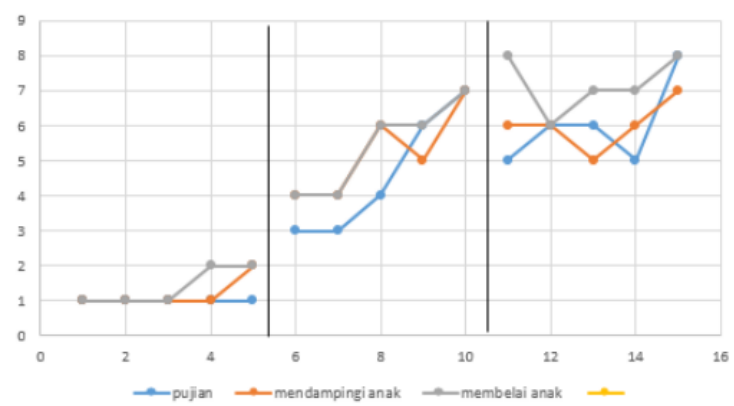

\section{Kondisi Psikologis Setelah Intervensi Subyek AC}

Kondisi psikologis yang diperlukan anak dapat membantu tumbuh kembang anak karena merupakan kebutuhan anak dalam masa perkembangannya. Anak terpenuhi kebutuhan psikologisnya akan berdampak positif salah satunya anak lebih percaya diri menghadapi lingkungan sosialnya.Tahap ini orang tua yang suda mendapatkan intervensi mengalami perkembangan dalam perlakuan attachment sehingga dampak yang terjadi akan berpengaruh pada perkembangan psikologis klien. Berikut tabel 13 yang menjelaskan kondisi psikologis anak, sebagai berikut :

\section{Tabel 13 Kodisi Perkembangan Psikologis Subyek AC}

\begin{tabular}{|c|c|c|c|c|c|c|}
\hline \multirow[b]{2}{*}{ No } & \multirow[b]{2}{*}{ Pernyataan } & \multicolumn{5}{|c|}{ Skor } \\
\hline & & $\begin{array}{c}\text { Selalu } \\
5\end{array}$ & $\begin{array}{c}\text { Sering } \\
4\end{array}$ & $\begin{array}{c}\text { Kadang--. } \\
\text { kadang } \\
3\end{array}$ & $\begin{array}{c}\text { Jarang } \\
2\end{array}$ & $\begin{array}{c}\text { Tidak } \\
\text { perna } \\
1\end{array}$ \\
\hline 1 & $\begin{array}{l}\text { Merasa di } \\
\text { dampingi }\end{array}$ & $\checkmark$ & & & & \\
\hline 2 & $\begin{array}{l}\text { Merasa dilindungi } \\
\text { oleh orang tua }\end{array}$ & & $\sqrt{ }$ & & & \\
\hline 3 & Merasa disayang & & $\sqrt{ }$ & & & \\
\hline
\end{tabular}

Tabel 4.56 di atas dapat diketahui total skor untuk kondisi psikologis subyekAC setelah melakukan intervensi yaitu sebesar 13, maka akan ditentukan skor total setiap responden kemudian dilanjutkan dengan menentukan range, banyak kelas serta interval untuk selanjutnya dibuat garis kontinum. Berikut ini perhitungan menurut Moh. Nazir (2005:380): Cara menghitung kriteria skor, yaitu:

$$
\begin{array}{ll}
\text { Skor Maksimal/Ideal } & =\text { Nilai Tertinggi } \times \text { Jumlah Soal } \times \text { Jumlah Sampel } \\
& =5 \times 3 \times 1=15 \\
& =\text { Nilai Terendah } \times \text { Jumlah Soal } \times \text { Jumlah Sampel } \\
& =1 \times 3 \times 1=3 \\
& =(\text { Skor Maks. }- \text { Skor Min. }): \text { kelas Interval (3) } \\
\text { Interval } & =(15-3): 3 \\
& =4
\end{array}
$$

Berdasarkan hasil di atas, maka diperoleh gambaran tentang Klien AC terhadap pemenuhan kebutuhan setelah perlakukuan psikologisnya:

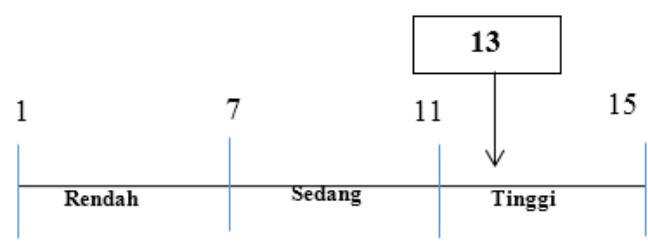

Garis Kontinum kondisi psikologis setelah intervensi pada subyek terhadap pemenuhan kebutuhan psikologisnya dalam kategori tinggi, hal ini menggambarkan bahwa terjadi peningkatan dari orang tua AC setelah mendapatkan perlakuan intersvensi. Orang tua yang memberikan memberikan Atachment kepada anak anak merasakan kasi sayang dari orang sehingga kelekatan yang dibangun oleh orang tua berpengaruh pada kebutuhan psikologis anak, hal yang dilakukan oleh orang tua memberikan kasi sayang kepada anak dan 
mendapingi anak sehingga perlakuan orang tua sangat berpengaruh pada pada psikologis anak

\section{Kondisi Atachment Setelah Intervensi}

Memberikan Attachment kepada anak akan meningkatkan kebutuhan psikologis anak sehingga terpenuhinya kebutuhan tumbuh kembang anak. hasil intervensi yang dilakukan ABFT dapat meningkatkan prilaku orang tua untuk melakukan attachmen yang menjadi salah satu hal yang yang dilakukan orang, intervensi yang dilakukan untuk orang tua AC menjadi kesadaran bagi ibu untuk terus meningkatkan kelekatan ke anakya, berikut tabel 14 pertanyaan mengenai prilaku attachment yang dilakukan orang tua sebagai:

Tabel 14 Kondisi Atachment Setelah Intervensi AC

\begin{tabular}{|c|l|c|c|c|c|c|}
\hline \multirow{2}{*}{ no } & \multicolumn{1}{|c|}{ Pernyataan } & $\begin{array}{c}\text { Selalu } \\
5\end{array}$ & $\begin{array}{c}\text { Sering } \\
4\end{array}$ & $\begin{array}{c}\text { Kadag- } \\
\text { kadang } \\
3\end{array}$ & $\begin{array}{c}\text { Jarang } \\
2\end{array}$ & $\begin{array}{c}\text { Tidak } \\
\text { perna } \\
1\end{array}$ \\
\hline 1 & Saya Mengajari anak & & $v$ & & & \\
\hline 2 & Saya Mengajak anak bercanda & & $v$ & & & \\
\hline 3 & Saya menyapa anak & $v$ & & & & \\
\hline 4 & $\begin{array}{l}\text { Saya mendampingi anak dalam } \\
\text { setiap kegaitannya }\end{array}$ & $v$ & & & & \\
\hline 5 & $\begin{array}{l}\text { Saya memberikan senyum kepada } \\
\text { anak }\end{array}$ & & $v$ & & & \\
\hline 6 & $\begin{array}{l}\text { Saya memberikan pujian kepda } \\
\text { anak }\end{array}$ & \multicolumn{5}{|c|}{} \\
\hline \multicolumn{5}{|l|}{} \\
\hline
\end{tabular}

Tabel 14 di atas dapat diketahui total skor setelah mendapatk attachment kepada anak yang dilakukan orang tua yaitu sebesar 26, maka akan ditentukan skor total setiap responden kemudian dilanjutkan dengan menentukan range, banyak kelas serta interval untuk selanjutnya dibuat garis kontinum. Berikut ini perhitungan menurut Moh. Nazir (2005:380):

Cara menghitung kriteria skor, yaitu:

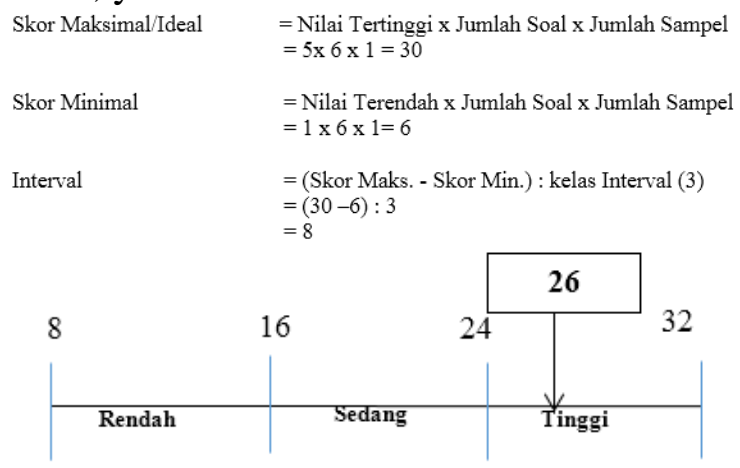

Berdasarkan hasil di atas, maka diperoleh gambaran tentang perlakukan Orang Tua Setelah Mendapatan Perlakuan Menunjukan Garis Kontinum Tinggi, Ini Orang Tua Memberikan Melakukan Attacment Dengan AC. Setelah Orang Tua Mendapatkan Terapi Orang Tua Mampu Memberikan Attachmen Kepada Anak orang tua melakukan attachmen kepada anak dengan melakukan pendampingan kepada anak dan mengajari anak ketika melakukan sesuatu kegiatan, kemudian orang tua meberikan pujian kepada anak ketika anak berhasil melakukan kegiatan.

Selain menggunakan angket penelitia menggunakan observasi untuk menggambarkan perbandingan pada fase intervensi B ke hasil A2 dapat dilihat dari tabel 15 sebagai berikut :

Tabel 15 Kondisi Atachment Setelah Intervensi AC

\begin{tabular}{|c|c|c|c|c|c|c|c|c|c|c|c|}
\hline \multirow{3}{*}{ No } & \multirow{2}{*}{ Perlakuan } & \multicolumn{5}{|c|}{ Intervensi B } & \multicolumn{5}{|c|}{ Hasil A2 } \\
\hline & & 6 & & 8 & & 10 & 11 & & & 14 & 15 \\
\hline & Pujian & 3 & 3 & 4 & 4 & 5 & 4 & 4 & 5 & 7 & 8 \\
\hline 2 & $\begin{array}{l}\text { Mendampingan } \\
\text { Anak }\end{array}$ & 3 & 3 & 5 & 5 & 5 & 4 & 5 & 5 & 7 & 8 \\
\hline 3 & Membelai anak & 3 & 3 & 4 & 6 & 6 & 5 & 5 & 6 & 8 & 8 \\
\hline
\end{tabular}

Attacmen Based Family Therapy (ABFT) digunakan untuk membantuk orang tua melakukan attachment untuk meningkatkan pemenuhan kebutuhan psikologis. attacmen Based Family therapy (ABFT) yang berkaitan dengan permasalahan orang tua yang kuarang 
melakukan kelekatan dengan anak sehingga tidak terpenuhinya kebutuhan psikologisnya, dalam permasalahan orang tua yang sering memarahi anak dan tidak mengerti kebutuhan anak sehingga timbul pengabaian kepada anak. orang tua yang tidak melekatkan diri kepada anak akan berpengaruh pada pemenuhan kebutuhan psikologis anak sehingga tidak menutup kemungkanan perkembangan secara psikologis akan menjadi masalah. masalah yang terjadi pada subyek HN adalah kesibukan orang tua yang berjualan pagi sampai soreh sehingga orang tua tidak dapat meluangkan waktunya bersama anak. terkadang orang tua mengabaikan anak dan membebaskan anak untuk melakukan sesuatu sehingga tidak melihat dampak dan resiko bahaya yang akan terjadi pada anak. sedangkan permasalahan AC yang terabaikan oleh orang tua karena prilaku AC yang tidak pernah mendengarkan orang tua, pendidikan AC juga terabaikan hal ini orang tua membebaskan AC apa yang dialakukan karana orang tua merasa lelah ketika memberikan teguran Kepada AC. melihat prilaku AC yang membuat orang tua tidak ingin menegur $\mathrm{AC}$ sehingga terkadang orang tua melakukan tidakan kekerasa kepada AC dengan alasan Agar AC mau mendengarkan dan menuruti yang ingin dilakukan AC.

\section{KESIMPULAN}

Hasil pengujian hiotesis prilaku ibu terdapa sub-sub hipotesis menunjukkan attachment antara orang tua dan anak penerapan Attachment Based Family Terapy (ABFT) dalam pengasuhan keluaraga dan Attachment Based Family Terapy (ABFT) mempengaruhi hubungan relasi anak dan keluarga Pemberian terapi ABFT membantu orang tua dalam meningkatkan attacmen dalam peningkatan kebutuhan psikologi anak pemeberian terapi ABFT merupakan sebuah aktivitas yang dilakukan dimana peneliti melakukan intervensi kepada subjek, untuk meningkatkan attacmen dalam peningkatan kebutuhan psikologi anak. melaui peningkatan kapasitas di harapkan ibu klien dapat memberikan attacment kepada klien HN, tetapi selama intervensi peneliti juga melakukan observasi

Pemberian interveni dilakukan selama 7 hari berdasarkan tahap-tapap dlam intervensi ABFT. tujuan dalam pelaksanaan terapi agar aggota keluarga membutuhkan kesadaran masing-masing yang mengalami masalah kelekatan antara keluarga dan anak. kegiatan ini memberika pehaman terhadap anggota keluarga agar dapat meningkatkan attacmen. adapun 5 langka yang dilakukan oleh terapis yaitu kerja sama dengan anak, kerja sama dengan orang tua, tugas kelekatan, dan tugas meningkatkan kompetensi . terjadi peningkatan perlakuan dari fase A-B-A, dengan terjadinya peningatan maka dapat di simpulakan bahaw teraai ABFT berpengaruh pada attachment dan meningkatkan pemenuhan kebutuhan psikologis anak.

\section{DAFTAR PUSTAKA}

Dubois, B. \& Miley, K. K. (2005). Social Work: An Empowering Profession. Boston: 1lyn and Bacon

Dubowitz, H. (2000). Handbook for Child Protection Practice. USA: SAGE Publication.

Durkin, K. (1995). Developmental Social Psychology. Massachussets: Blackwell Publisher Inc.

Erikson, H. (1968). Identity, youth, and Crisis. New York: International University Press.

Ervika, E. (2000). Kualitas Kelekatan dan Kemampuan Berempati pada Anak. Skripsi Fakultas Psikologi Universitas Gadjah Mada.

Hurlock, E. B. (1993). Perkembangan Anak Jakarta: Erlangga.

Ife, J., \& Tesoriero, F. 2(008). Community Development. Yogyakarta: Pustaka Pelajar.

Khairuddin. (2002). Sosiologi Keluarga .Yogyakarta: Liberty.

Konvensi ILO Nomor 182 tahun 1999 tentang Pelarangan dan Penghapusan Segera BentukBentuk Terburuk Pekerjaan Untuk Anak 
Lebow, J. L., \& Pinsof, W. M. (2005). Family Psychology: The Art of the Science. London: Oxford University Press.

Papalia, D. E., Old, S. W., Feldman, \& R.D. (2001). Perkembangan Manusia. Jakarta: Salemba Humanika

Piaget, J., \& Inhelder, B. (2010). Psikologi Anak, Terj. Miftahul Jannah, Yogyakarta: Pustaka Pelajar

Papalia D.E., Olds, S.W, \& Feldman, R. D. (2009). Human Development (Perkembangan Manusia edisi 10 buku 2). Jakarta: Salemba Humanika.

Peraturan Menteri Sosial Republik Indonesia No 8 Tahun 2012 tentang Anak Terlantar

Pincus, A., \& Minahan, A. (1973). Social work practice; model and method. F.E. Peacock Publishers, Inc., Hasco. Illeanis.

Suharto, E. (2006). Membangaun Masyarakat Memberdayakan Rakyat. Bandung: Refika Aditama.

Suhendi, H., \& Wahyu, R. (2001). Pengantar Studi Sosiologi Keluarga. Bandung: Pustaka Setia.

Sunanto, J. (2006). Penelitian dengan Subjek Tunggal. Bandung: UPI Press.

Sugiyono. (2010). Metode Penelitian Kuantitatif dan Kualitatif \& RND. Bandung: Alfabeta.

Soehartono, I. (2008). Metode Penelitian Sosial: Suatu Teknik Penelitian Bidang Ilmu Kesejahteraan. Bandung: Remaja Rosdakarya.

Undang-Undang No 4 tahun 1974 tentang Kesejahteraan Anak

Undang-Undang Nomor 3 tahun 1997 tentang Pengadilan anak

Undang-Undang Nomor 2 Tahun 1988 Tentang Usaha Kesejahteraan Anak

Undang-Undang Nomor 23 tahun 2002 tentang Perlindungan Anak

Zastrow, H. C. (1982). Introduction to Social Welfare Institutions: Social Problems, Services and Current Issues. Illinois: The Dorsey Press

Zastrow, H. C. (1999). The practice of social work. USA : Brooks/Cole Publishing Company 